IAB-DISCUSSION PAPER

30|2020 Wind of Change? Cultural Determinants of Maternal Labor Supply

Barbara Boelmann, Anna Raute, Uta Schönberg 


\section{Wind of Change? Cultural Determinants of Maternal Labor Supply}

Barbara Boelmann (CReAM, University College London and University of Cologne)

Anna Raute (CReAM, Queen Mary University of London and CEPR)

Uta Schönberg (CReAM, University College London and IAB)

Mit der Reihe „IAB-Discussion Paper“ will das Forschungsinstitut der Bundesagentur für Arbeit den Dialog mit der externen Wissenschaft intensivieren. Durch die rasche Verbreitung von Forschungsergebnissen über das Internet soll noch vor Drucklegung Kritik angeregt und Qualität gesichert werden.

The "IAB-Discussion Paper" is published by the research institute of the German Federal Employment Agency in order to intensify the dialogue with the scientific community. The prompt publication of the latest research results via the internet intends to stimulate criticism and to ensure research quality at an early stage before printing. 


\section{Content}

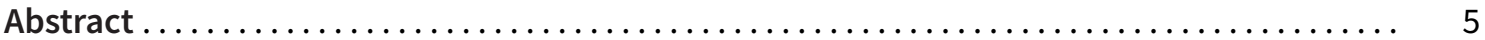

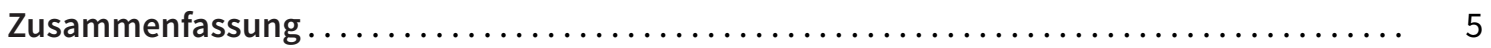

Acknowledgement $\ldots \ldots \ldots \ldots \ldots \ldots \ldots \ldots \ldots \ldots \ldots \ldots \ldots \ldots \ldots \ldots \ldots \ldots \ldots \ldots$

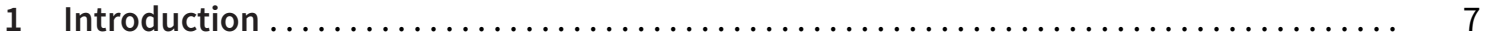

2 The Division and Reunification of Germany $\ldots \ldots \ldots \ldots \ldots \ldots \ldots \ldots \ldots \ldots \ldots \ldots$

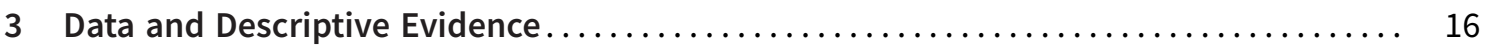

3.1 Data Description and Sample Selection $\ldots \ldots \ldots \ldots \ldots \ldots \ldots \ldots \ldots \ldots \ldots \ldots \ldots \ldots$

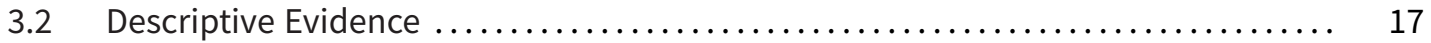

4 The Legacy of East German Culture: Evidence from the Former Border . . . . . . . . 20

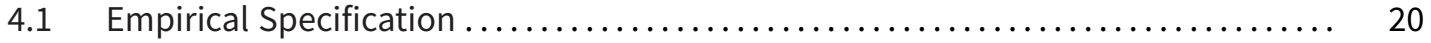

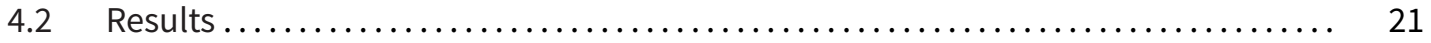

5 How Persistent is Childhood Culture? Evidence from Migrants . . . . . . . . . . . . ... 24

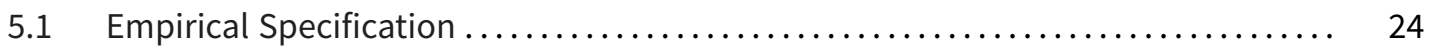

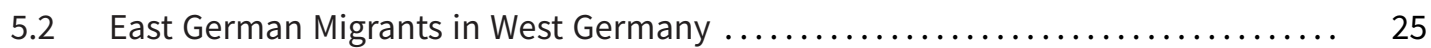

5.3 West German Migrants in East Germany .......................... 28

6 Current versus Past Exposure to a More Gender Egalitarian Culture -- Evidence from

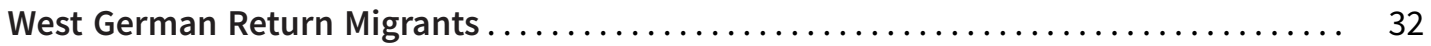

7 Horizontal Transmission within West German Firms - Evidence from the Arrival of East German Colleagues..................................... 34

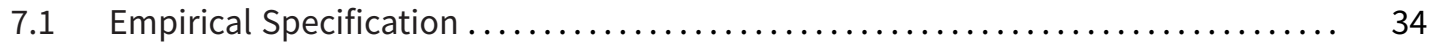

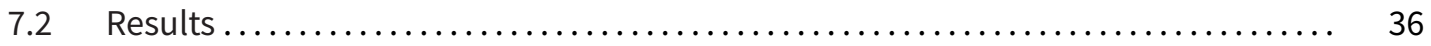

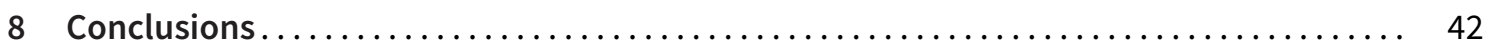

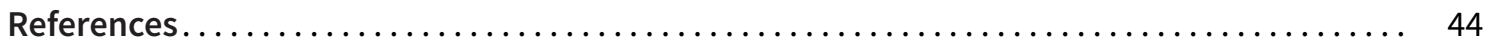

Appendix: Imputation of East and West Germans . . . . . . . . . . . . . . . 49 


\section{List of Figures}

Figure 1 Mama vs Mutti - Advertising in the 1950s........................ 13

Figure 2 Cross-Country Differences in Gender Norms (European Values Study) ........ 15

Figure 3 Return-to-Work Behavior and Child Penalties: East versus West German Mothers 18

Figure 4 The East-West Gaps in Maternal Employment by Time To and Since Childbirth: Integrated Cross-Border Labor Markets ......................... 23

Figure 5 The effect of East German Colleagues on Regular Employment of West German Mothers One Year After Childbirth (Event Study) .................. 38

Figure 6 The effect of East German Colleagues on Regular Employment of West German Mothers One Year After Childbirth by Treatment Intensity ............. 42

Figure A.1 Cross-Border Local Labor Markets ............................ 50

\section{List of Tables}

Table 1 Differences in Post-Birth Employment Outcomes between East and West German Mothers: Overall Germany vs Integrated Cross-Border Local Labor Markets.....

Table 2 Differences in Post-Birth Employment Outcomes between East and West German Mothers in West Germany .................................. 26

Table 3 Differences in Post-Birth Employment Outcomes between East and West German Mothers in West Germany: Robustness Checks .................... 28

Table 4 Differences in Post-Birth Employment Outcomes between East and West German Mothers in East Germany ................................. 29

Table 5 Differences in Post-Birth Employment Outcomes between East and West German Mothers in East Germany: Robustness Checks....................... 31

Table 6 Does past exposure to a more gender egalitarian culture matter? - Differences in post-birth employment outcomes between West German return migrants and

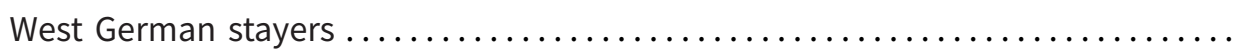

Table 7 The Effects of East German Colleagues on Post-Birth Employment Outcomes of

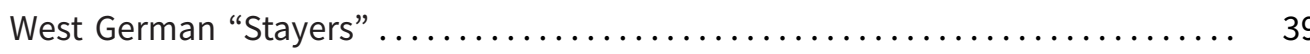

Table 8 The Effects of East German Colleagues on Post-Birth Employment Outcomes of West German "Stayers" (Robustness Checks)...................... 40

Table 9 The Effects of East German Colleagues on Post-Birth Employment Outcomes of West German "Stayers": Heterogeneous Effects .................... 41

Table A.1 East and West German Migrants and Stayers: Descriptive Statistics ......... 51 


\section{Abstract}

Does the culture in which a woman grows up influence her labor market decisions once she has had a child? To what extent might the culture of her present social environment shape maternal labor supply? To address these questions, we exploit the setting of German reunification. A state socialist country, East Germany strongly encouraged mothers to participate in the labor market full-time, whereas West Germany propagated a more traditional male breadwinner-model. After reunification, these two cultures were suddenly thrown together, with consequent increased social interactions between East and West Germans through migration and commuting. A comparison of East and West German mothers on both sides of the former Inner German border within the same commuting zone shows that culture matters. Indeed, East German mothers return to work more quickly and for longer hours than West German mothers even two decades after reunification. Second, in exploiting migration across this old border, we document a strong asymmetry in the persistence of the culture in which women were raised. Whereas East German female migrants return to work earlier and work longer hours than their West German colleagues even after long exposure to the more traditional West German culture, West German migrants adjust their post-birth labor supply behavior nearly entirely to that of their East German colleagues. Finally, taking advantage of differential inflows of East German migrants across West German firms in the aftermath of reunification, we show that even a partial exposure to East German colleagues induces "native" West German mothers to accelerate their return to work after childbirth, suggesting that migration might be a catalyst for cultural change.

\section{Zusammenfassung}

Werden die Arbeitsmarktentscheidungen von Müttern von der Kultur beeinflusst, in der die Frauen aufgewachsen sind? Und wie wirkt sich das aktuelle soziale Umfeld auf das Arbeitsangebot von Müttern aus? Um diese Fragen zu beantworten, vergleichen wir ost- und westdeutsche Frauen im Kontext der deutschen Wiedervereinigung. Im sozialistischen Osten wurde die Vollzeiterwerbstätigkeit von Müttern forciert, während in Westdeutschland das traditionelle Modell des männlichen Hauptverdieners verbreitet war. Nach der Wiedervereinigung wurden beide Kulturen plötzlich miteinander konfrontiert und dieser Austausch wurde durch die darauffolgenden Migrations- und Pendlerströme weiter verstärkt. Vergleicht man ost- und westdeutsche Mütter entlang der ehemaligen innerdeutschen Grenze innerhalb desselben grenzüberschreitenden lokalen Arbeitsmarktes, zeigt sich, dass Kultur für deren Arbeitsmarktentscheidungen eine entscheidende Rolle spielt. Selbst 20 Jahre nach der Wiedervereinigung kehren ostdeutsche Mütter früher in ihren Beruf zurück und arbeiten mehr Stunden als westdeutsche Mütter. In einem zweiten Schritt betrachten wir ost- und westdeutsche Migrantinnen im jeweils anderen Landesteil und zeigen, dass die ost- und westdeutsche Kindheitskultur unterschiedlich persistent ist. Während ostdeutsche Migrantinnen früher nach der Geburt ihres Kindes in den Beruf zurückkehren und auch mehr Stunden arbeiten als ihre westdeutschen Kolleginnen selbst wenn sie schon lange in der traditionelleren westdeutschen Kultur gelebt haben, passen sich westdeutsche Migrantinnen in ihrem Arbeitsangebot nach der Geburt fast komplett ihren ostdeutschen Kolleginnen an. 
In einem letzten Schritt nutzen wir aus, dass westdeutsche Firmen unterschiedlich stark von Migrationsströmen von Ost nach West betroffen waren und finden, dass westdeutsche Frauen selbst in ihrem eigenen kulturellen Umfeld durch den Kontakt zu ostdeutschen Frauen ihr Verhalten ändern und früher nach der Geburt ihres Kindes in den Beruf zurückkehren. Dies deutet darauf hin, dass Migration ein Katalysator für kulturellen Wandel sein kann.

\section{JEL classification}

$\mathrm{J} 1, \mathrm{~J} 2, \mathrm{Z} 1$

\section{Keywords}

cultural transmission, social norms, maternal labor force participation, German reunification

\section{Acknowledgement}

We are indebted to Malte Sandner from IAB for assistance with the data. We have benefitted from discussions with Natalie Bau, Anja Prummer, Heather Sarsons, and Michel Serafinelli. We thank seminar and conference participants at QMUL, Zurich, Bristol, UCL, Oxford, CEU, Cologne, Briq, Düsseldorf, Collegio Carlo Alberto, LMU Munich, U Chicago, NHH Bergen, Seoul National University, 2018 Wolfe Workshop, 2019 AEA meetings, 2019 COSME gender economics workshop, 2019 Southampton Applied Workshop and 2019 IZA Summer School among others for helpful comments. Anna Raute gratefully acknowledges funding from the Fritz Thyssen Foundation and Uta Schönberg that from the European Research Council (project Firmineq). 


\section{Introduction}

Gender role attitudes and female labor supply vary substantially across countries. A recent literature has stressed that these differences arise from persistent and deeply rooted cultural traits that are transmitted from one generation to the next (Fernández 2007; Fernández and Fogli 2009; Alesina, Giuliano, and Nunn 2013). Yet, gender norms and female labor supply - in particular that of mothers - have also dramatically changed over time (see Giuliano $(2018$; 2016) for an overview on the literature on gender norms). ${ }^{1}$ The evidence on both the continuity and the evolution of gender norms raises the question as to when culture persists and when it changes. Moreover, to what extent does diffusion occur when different cultural groups interact?

In this paper, we explore a number of specific questions to this regard. Does, for example, a woman raised in a gender egalitarian culture, but who migrates to a more traditional environment, still behave according to the culture she grew up in ("childhood culture") or does she adapt to her new environment ("current culture")? Conversely, what about a woman who migrates from a more traditional environment to one that is more gender egalitarian? Can migrants from a more gender egalitarian culture even induce change in the behavior of women raised and working in the more traditional host country?

In the empirical literature, culture is commonly defined as systematic differences in both values or preferences and beliefs that vary across social or geographic groups (see, for instance, Fernández 2011; Alesina and Giuliano 2015). ${ }^{2}$ Fernández and Fogli (2009) argue that the values and beliefs held by each woman can influence her behavior directly. Additionally, those held by individuals in her social network (e. g., family, coworkers, and neighbors) can also affect her behavior through a variety of social influences. Culture can thus influence a mother's work behavior in a number of ways. One the one hand, through vertical transmission from one generation to the next ${ }^{3}$ within the immediate family, but also by way of her broader social network (e. g., friends and neighbors) ${ }^{4}$ and larger society (e. g. schools and media), highlighting the importance of "childhood culture." On the other hand, cultural traits can also be transmitted "horizontally" through social interaction in adulthood with neighbors or co-workers from different backgrounds (see Bisin and Verdier 2011)-illustrating the weight of "current culture."

In order to isolate the effect of culture from the institutional and economic environment-the crucial challenge in this literature (Alesina and Giuliano 2015) -we exploit Germany's separation and reunification. From 1945 to 1990, the country was divided into two parts. Socialist East Germany (GDR) strongly encouraged mothers to participate in the labor market, whereas capitalist West Germany (FRG) propagated a more traditional male breadwinner-model. Gender norms and female labor supply, particularly at early motherhood, diverged strongly between East and West during

\footnotetext{
1 Two broad lines of reasoning have been put forward to explain why cultural change occurs: instability in a given environment and economic pressure (e. g., Giuliano and Nunn 2019; Cardoso and Morin 2018) and new information (e. g., Fernández 2013, Fernández, Parsa, and Viarengo 2019, Bursztyn, González, and Yanagizawa-Drott 2018).

2 Guiso, Sapienza and Zingales $(2006,23)$ stress the persistence of culture by defining the latter as "those customary beliefs and values that ethnic, religious, and social groups transmit fairly unchanged from generation to generation."

3 In line with the vertical transmission of culture, a number of papers have documented a strong correlation in labor force participation rates and gender role attitudes between mothers and daughters (e. g., Thornton, Alwin, and Camburn 1983; Farré and Vella 2013; Olivetti, Patacchini, and Zenou, forthcoming).

4 Bisin and Verdier (2011, 342) refer to cultural transmission from non-parental elders - e. g., adolescent peers' parents as studied by Olivetti, Patacchini and Zenou (forthcoming) - to children as "oblique socialization."
} 
the four decades of separation. With the fall of the Iron Curtain and German reunification, these two cultures were suddenly thrown together, with East Germany adopting West Germany's political, economic, and legal institutions. A large number of East and West Germans migrated or commuted across the former Inner German Border, leading to increased social interactions in the workplace or neighborhood between women raised in very different cultures. Whereas the existing literature has used German separation and reunification to identify the legacy of socialism on preferences for redistribution (Alesina and Fuchs-Schündeln 2007), or gender attitudes and preferences (Campa and Serafinelli 2018; Bauernschuster and Rainer 2011; Beblo and Görges 2018), our study is novel in that we exploit the migration wave in the aftermath of reunification to study the persistence and diffusion of a more gender egalitarian versus a more traditional culture.

We focus in particular on the impact of culture on women's labor supply decisions after they have had their first child. The transition around childbirth is especially interesting for two main reasons. First, the arrival of children is one of the primary reasons for persistent gender inequalities in the labor market (Angelov, Johansson, and Lindahl 2016; Kleven, Landais, and Søgaard 2019). Second, differences in gender norms and culture across countries likely play an important role in determining what women are "supposed to do" when becoming a parent and what it means to be a "good mother" (see Fortin 2005). This in turn may help explain differences in maternal labor supply and earnings losses post childbirth across countries (see Kleven, Landais, Posch, Steinhauer, and Zweimüller 2019, for an overview of how child penalties differ across countries). ${ }^{5}$

Culture is therefore indubitably quite salient when it comes to decisions revolving around childbearing (an effect that mothers often underestimate, as shown by Kuziemko, Pan, Shen, and Washington, 2018). As gender norms regarding working mothers are arguably the strongest when children are very young, we expect culture to affect female labor force participation decisions particularly in the first years of a child's life. Exploring women's labor market decisions around childbirth thus allows, on the one hand, to study changes in a woman's labor supply before and after childbirth or, on the other hand, to condition on a woman's pre-birth work history, in an effort to isolate the effects of culture from other confounding factors.

Our empirical analysis draws on high quality social security data permitting observation not only of the complete work histories of a 50 percent random sample of women born between 1946 and 1994, but also of those employed in the same workplace. We focus primarily on East and West German women who gave birth for the first time in the mid-2000s. These two groups grew up under very different regimes until their early teens, but then made important education and labor market decisions after reunification under common institutions in a market economy. A comparison of the return-to-work behavior of East and West German first-time mothers provides a first piece of evidence that (childhood and current) culture is an important determinant of early maternal employment. In contrast to West German mothers, a sizable share of East German mothers returns to work exactly 12 months after birth, when leave benefits and job protection would have expired under the past GDR regime, despite the fact that the current parental leave legislation does not incentivize them to do so. This suggests that even 15 years post reunification East German women behave according to the norms prescribed by the old GDR institutions.

\footnotetext{
5 Descriptive evidence suggests that beliefs about gender roles, in particular the clash between egalitarian views and family values (so called "mother's guilt"), and women's labor force participation rates are strongly correlated across countries (Fortin 2005) and over time within the United States (Fortin 2015).
} 
We adopt four empirical strategies in an attempt to disentangle the impact of culture on early maternal employment from other factors. In a first step we compare, building on Eugster, Lalive, Steinhauer, and Zweimüller (Eugster et al. 2011; 2017), Steinhauer (2018), and Campa and Serafinelli (2018), post-birth labor market outcomes of East and West German mothers within the same crossborder local labor market, thereby holding their economic environment constant. The East-West divide at the border captures the combined effects of childhood and current culture; these two groups of mothers not only differ in terms of the culture they grew up in, but also with respect to their social network in adulthood (i. e., the share of East or West German neighbors and colleagues). We find that four years after childbirth, East German mothers are 11.6 percentage points more likely to be "regularly" employed (making more than 400 EUR a month) than observably similar West German mothers - an effect of 29 percent if evaluated against the mean employment probability of 40.1 percent for West German mothers. In line with our descriptive evidence, this gap starts to emerge one year after childbirth, at time when leave benefits and job protection would have expired under the past GDR regime. Moreover, it persists thereafter, even once the child enters elementary school.

In a second step, we contrast, building on the epidemiological approach (see e.g., Fernández 2011 for an overview), the post-birth labor supply behavior of East German cross-border migrants and West German "natives"-or West German cross-border migrants and East German "natives" respectively - within the same local labor market and even within the same workplace. ${ }^{6}$ We thereby hold constant not only mothers' economic environment, but also their current social network. This approach thus isolates the impact of childhood culture for women now immersed as a minority in a different majority culture. Similar to Gay (2019) for France and Charles, Guryan, and Pan (2018) for the US-although in contrast to other studies (e. g., Fernández 2007, Giuliano 2007, Fernández and Fogli 2009, and Blau et al. 2013) -we focus on first-generation internal migrants who speak the same language and are ethnically the same as "natives" (as opposed to second-generation international migrants) in order to identify the role of childhood culture in shaping the labor supply decisions of mothers. Our paper is the first, to our knowledge, that explicitly assesses a potential asymmetry in the persistence of childhood culture by distinguishing between migration flows from a more gender egalitarian childhood culture to a more traditional current culture and vice versa.

We do, in fact, document a large asymmetry in the persistence of childhood culture. Whereas East German female migrants return earlier and work longer hours than their West German counterparts, and this even after long exposure to the more traditional West German culture, West German migrants adjust their post-birth labor supply behavior nearly entirely to that of their East German colleagues. Four years after childbirth, East German migrants are 7.9 percentage points more likely to be regularly employed than their observationally equivalent West German peers. This gap is smaller than the East-West divergence of 11.6 percentage points within the same cross-border local labor market, which captures a combination of childhood and current culture, implying that for women raised in a more gender equal culture, the beliefs and values of their childhood play a more important role (68 percent $(0.079 / 11.6)$ ) in shaping their labor supply decisions as new mothers than does their current cultural environment (32 percent). In contrast, for women who grew up in a more traditional culture, being exposed to a gender egalitarian environment in adulthood

\footnotetext{
6 In a similar vein, Grunow and Müller (2012) descriptively compare the post-birth labor supply behavior of East German, West German and women who moved from East to West. They document that East to West movers return to work faster than West German mothers, but not as fast as East Germans who stayed in East Germany.
} 
clearly trumps their more traditional childhood culture, highlighting the importance of the horizontal transmission of culture from East German colleagues and neighbors to West German migrants. East-West gaps are similar when comparing cross-border migrants to internal migrants, i. e., West and East Germans who migrated a similar distance but without crossing the former Inner German Border, or when restricting the sample to firms within the cross-border local labor market where many East and West Germans commute across the former divide, indicating that the East-West gaps do not merely reflect a general "migration" effect.

In a third step, we compare post-birth labor market outcomes of West Germans who spent at least two years in East Germany before returning to West Germany and West Germans who never left West Germany. We document that West German mothers continue to be influenced by the more gender equal East German culture even after they moved back to the more traditional West Germany. Four years after childbirth, West German return migrants are 3.9 percentage points more likely to be regularly employed than observationally equivalent West German mothers who always remained in West Germany. This gap is smaller than that of 7.9 percentage points between East German migrants and West German "stayers," suggesting that exposure to a more gender equal culture in adulthood alone has about half the effect on early maternal labor supply as having been brought up in this gender equal culture as a child. The persistent impact of past exposure to East German culture further points toward the importance of information transmission from older East Germans (between generations, as in Fernández 2013) or from similarly aged East German peers (as in Fogli and Veldkamp 2011) in helping to ease concerns over the impact of returning to work on their children and own well-being, rather than peer pressure to conform with East German gender norms. Alternatively, immersion in a more gender egalitarian culture as young adults may induce a permanent change in women's work preferences or identity. ${ }^{7}$

In the fourth step of the paper, we investigate whether an even more moderate exposure to a more gender egalitarian East German culture, rather than full immersion, can result in cultural diffusion. Exploiting the differential inflow of East Germans into West German firms shortly after reunification in a difference-in-differences approach, we assess whether the sudden arrival of colleagues from the more gender egalitarian East German culture affected the labor supply behavior of West German "native" mothers socialized and still residing in the more traditional culture. We find that a 10percentage point increase in the employment share of East Germans in the firm increases the probability that a West German mother is employed by up to 2 percentage points in the short run (one year after childbirth), and by up to 1.6 percentage points in the medium run (four years after childbirth). Comparing these estimates to the employment gaps between West German return migrants and West German stayers, a partial but present-day exposure appears to have a somewhat smaller impact than a full but past exposure to the more gender egalitarian East German culture. The effect of East German peers on maternal labor supply is primarily driven by GDR female colleagues, who likely transmit first-hand knowledge of how to combine work and parenthood. A battery of robustness checks, including placebo checks on older women and men, further corroborate our findings. Finally, our estimates suggest that a substantial migration shock of at least 10 percentage points is needed to induce changes in the post-birth labor supply behavior of West German mothers.

\footnotetext{
7 In line with this hypothesis, Olivetti, Patacchini and Zenou (forthcoming) show that being surrounded by more peers with working mothers during adolescence affects women's attitudes about potential conflict between work and motherhood.
} 
This last part of our paper complements two recent studies on the effect of migration on the cultural diffusion of gender norms. Jarotschkin and Zhuravskaya (2019) provide evidence for betweengroup horizontal transmission of gender norms from Stalin's ethnic deportees to exposed local populations across regions of the former USSR. In a similar vein, Schmitz and Weinhardt (2019) document that West German women increased their hours of work in areas with high immigration rates from former East Germany, relative to areas with low such immigration rates. Our fourth set of findings also relate to the literature on peer effects in labor supply, which documents the role of adolescent peers' parents (Olivetti, Patacchini and Zenou, forthcoming), that of neighbors (Maurin and Moschion 2009), as well as peers within the family (Nicoletti, Salvanes, and Tominey 2018) in shaping mothers' labor supply. We go beyond these studies not only by painting a more comprehensive picture of the persistence and diffusion of culture through presenting evidence from these four different approaches, but also by focusing on changes in women's labor supply at the onset of motherhood, precisely when cultural influences are particularly salient. Moreover, we assess the exposure to a different cultural group at the workplace rather than larger geographical level, and thus where social interaction and information transmission about how to combine work and family are arguably greater.

Overall, our findings highlight that culture is a key determinant of women's labor supply behavior after childbirth. West German mothers would be 11.6 percentage points more likely to be employed four years after childbirth if they had grown up in the more gender egalitarian East German culture and had been surrounded by a similar share of East German neighbors and colleagues as were East German mothers at the time of birth. This effect is, in fact, larger in magnitude than employment gaps between college educated and non-college educated young mothers observed in the US and UK (Kuziemko, Pan, Shen, and Washington 2018). Interestingly, more egalitarian gender roles persist even when women have been fully immersed in a more traditional environment for a prolonged period of time. Conversely, more traditional gender norms are prone to change due to imitation and information transmission in direct exposure to a more gender egalitarian culture. Furthermore, our study demonstrates that migrants from a more gender egalitarian culture can bring about cultural change among women socialized and working in a more traditional environment, provided that the exposure is large enough.

\section{The Division and Reunification of Germany}

At the end of World War II in 1945, Germany was separated, with negotiations between the Soviet Union and Western Allies determining its borders. In 1949, the German Democratic Republic (GDR) and the Federal Republic of Germany (FRG) were officially established in the Soviet occupation zone and Allied occupation zone respectively. With the construction of the Berlin Wall in August 1961, migration between the two states nearly stopped and social interactions between East and West German citizens were severely restricted until its collapse in November 1989.

Gender-Egalitarian Culture in the GDR. The equality of women being a proclaimed goal of statesocialist governments, the GDR granted women the constitutional right to work and to receive equal 
pay already in 1949. While the GDR developed into "one of the most rigid" state-socialist regimes (Alesina and Fuchs-Schündeln 2007, 1510), scholars also argue that it "went furthest in balancing its policies towards women as producers and reproducers" (Einhorn 1993 cited in Trappe 1996, 355).

As early as the 1950s, the GDR introduced policies to promote women's educational attainment and increase female labor force participation in view of a need for labor. By the end of this decade, the regime was propagating the obligation to work (Trappe 1996). Ideologically, housewives were devalued, with non-working mothers described as "Schmarotzer" (parasites) (Kaminsky 2016, 93). ${ }^{8}$ Female labor force participation increased from 52.4 percent in 1950 to 81.8 percent in 1970 (Beblo and Görges 2018); considerably higher than in Scandinavian countries such as Sweden at the time (Gustafsson and Jacobsson 1985). Yet high female labor force participation created a "double burden" for women who were also the primary caregivers and contributors to home production.

The country was one of the first to introduce contraception and legalize abortion, aimed at allowing women to time their fertility and invest in their careers. As fertility levels started to decline in the 1960s, the GDR began to focus on policies that would help women reconcile work and family. Throughout the 1970s and 1980s it expanded public provision of childcare, offered one year of paid parental leave with full wage compensation and job protection (the "baby year"), and reduced working hours for mothers with small children (Trappe 1996).

Gender-Traditional Culture in the FRG. While East Germany encouraged mothers of small children to return to work through family policies and state propaganda, West Germany discouraged them by promoting a more traditional male-breadwinner model (Trappe 1996). ${ }^{9}$ In the FRG, school schedules were short (typically ending around lunch time) and childcare centers were scarce, particularly for children younger than four, and mostly part-time. Paid parental leave was subsequently expanded throughout the late 1970s and 1980s from two months of benefits and job protection in 1979 to 18 months in 1989 (for further details, see Schönberg and Ludsteck 2014). However, incomereplacement was considerably less generous than in the GDR, amounting, on average, to about one third of the mother's pre-birth wage. A tax and benefit system marked by joint taxation and free insurance of non-employed spouses and children further discouraged dual-earner families. More traditional gender role attitudes were also apparent in jargon used in West Germany such as "Rabenmutter" (literally, raven mother), a derogatory term used for working mothers, or day care centers as "Fremdbetreuung," which translates into "care by strangers." Figure 1 illustrates how the different gender norms in East and West Germany were respectively depicted in advertisements for household products in the 1950s.

\footnotetext{
8 The GDR Criminal Code even classified the avoidance of work as anti-social behaviour, making it a criminal act punishable by prison for up to 5 years (Beblo and Görges 2018, 22).

9 Up until 1958, the husband had full decisional power over his wife and children, and up until 1977, German civil law stated that a wife only had the right to be employed as far it was compatible with her marriage and family duties.
} 

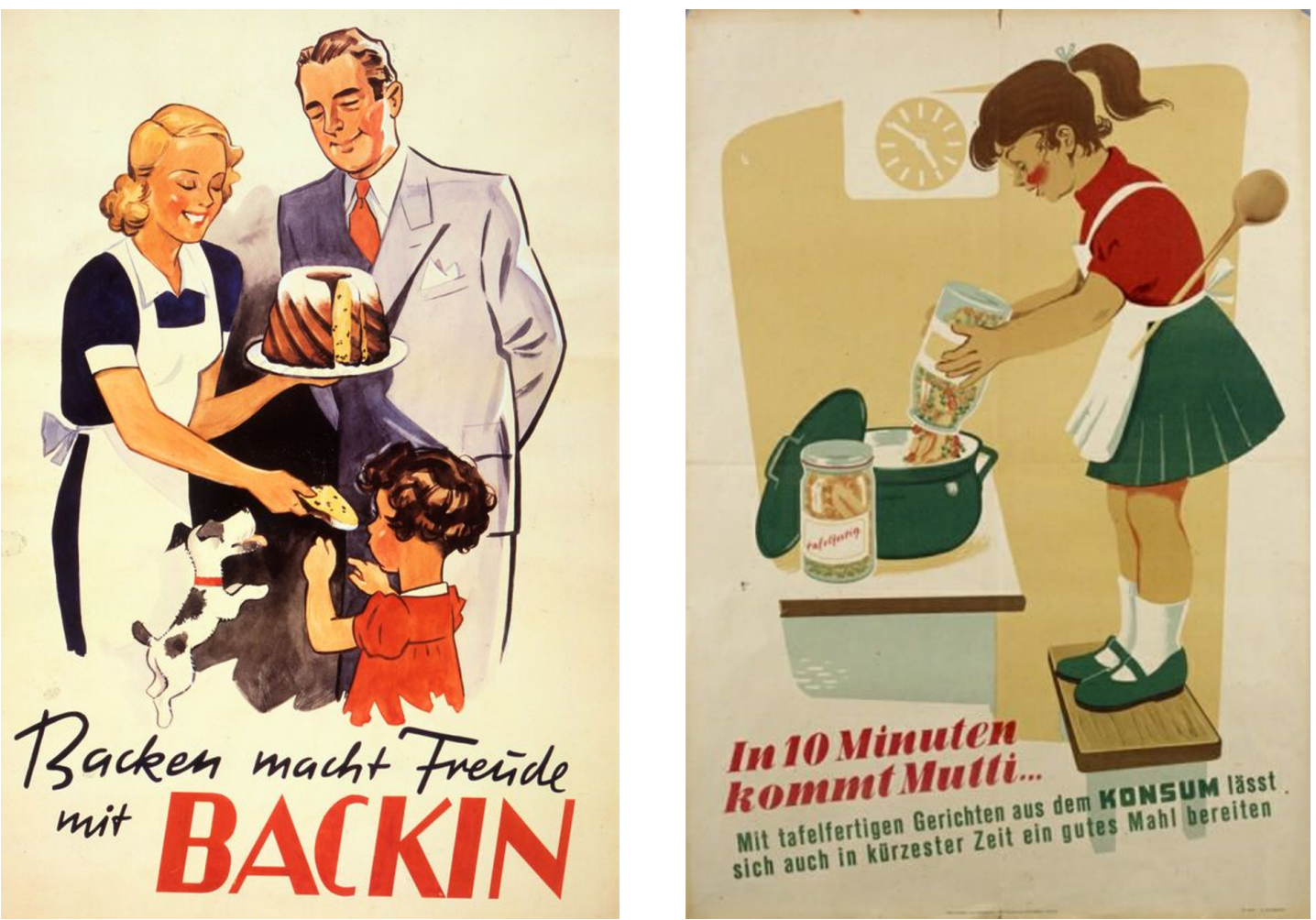

Notes: The figure depicts an example from advertisements for household products in West (Part A) and East (Part B) Germany in the 1950s. The text in Part A from 1950 translates as "Baking is fun using BACKIN". The text in Part B from 1955 translates as "Mom is coming home in 10 minutes... Using ready-made dishes by KONSUM allows one to prepare a good meal in the shortest period of time". Note that "Mutti" was widely used in East Germany, while "Mama" is more common in West Germany. Source: Part A: Oetker-Firmenarchiv S2/86. Part B: Stadtgeschichtliches Museum Leipzig PL 55/11.

After more than four decades of diverging institutions and family policies, women's labor force participation rates in these two countries greatly differed: In 1989, shortly before reunification, around 89 percent of women worked in the GDR, one of the highest rates in the world, against 56 percent in West Germany (Rosenfeld, Trappe, and Gornick 2004). While nearly 75 percent of East German women worked a standard full-time week, only 30 percent of working-age women in the West were employed full-time (Trappe and Rosenfeld 2000). Differences in labor supply were particularly pronounced for mothers. ${ }^{10}$

German Reunification. With the collapse of the Soviet Union and large-scale demonstrations against the East German regime, the Berlin Wall fell on November 9, 1989 and reunification occurred on October 3, 1990. Subsequent migration flows between East and West Germany were large: During the years 1991 to 2006, 2.45 million people migrated from the former GDR to the former FRG, while 1.45 million individuals moved in the opposite direction (Fuchs-Schündeln and Schündeln 2009). With reunification, the GDR became part of the FRG and adopted West Germany's political, economic, and legal institutions, including its tax and parental leave systems. In 1992, reunified

10 Becker, Mergele, and Woessmann (2020) argue that these East-West differences in female labor force participation rates may not only reflect differences in the political regimes between East and West Germany, but also differences prior to the division or selective East-West migration before the building of the Berlin wall in 1961. This does not pose an issue for our study as we do not aim to identify the long-lasting effects of state-socialism. 
Germany expanded its parental leave policy, with mothers now being entitled to 36 months of job protection and up to 24 months of means-tested paid parental leave benefits of up to 300 Euros per month (from 1993 onwards). The primary goal behind this long leave was to ensure child welfare by reducing early maternal employment (e. g., Schönberg and Ludsteck 2014). The law thus clearly reflects the more traditional gender norms of West Germany, rather than the more egalitarian gender norms of East Germany. ${ }^{11}$

In 1996, the country introduced a law that entitled every child to a heavily subsidized half-day childcare placement from their third birthday to school entry (e. g., Cornelissen, Dustmann, Raute, and Schönberg 2018). By the early 2000s, the policy had removed any constraints in child care availability for 3-to-6 year-olds that may have previously existed in West Germany. While childcare supply in the East was historically high, it was cut back drastically over the years 1991-1998 due to both economic pressure and in response to a drop in fertility rates. Yet in 2007, the time around which women in our sample gave birth, the percentage of children under the age of three attending day care was still much higher in former East Germany (37.4) than former West Germany (8.1). Attendance rates of children aged three to six were, however, roughly similar (93.6 versus 87.8 percent; Statistische Ämter des Bundes und der Länder 2008).

Today, reunified Germany continues to be characterized by relatively traditional gender attitudes. According to the 2008 European Value Survey (EVS 2014), 56 percent of the German respondents agree with the statement that "A pre-school child suffers if his or her mother works," compared to 17 percent and 8 percent in the more gender equal countries of Sweden and Denmark. This percentage is, however, well below that of Italy (70 percent), the most gender-traditional country according to this measure (Part A of Figure 2). Yet the German figure masks strong differences between the two parts of the country: whereas 57 percent of respondents in West Germany agree with the statement, only 31 percent of those in East Germany do so (Part B of Figure 2), a share comparable to Western European countries such as Great Britain and France, but still higher than in the Scandinavian countries. Hence, nearly two decades after reunification, East and West Germans still have very different attitudes relative to the roles of mothers. This descriptive pattern is in line with existing empirical evidence showing that exposure to state-socialism did in fact reduce gender gaps in preferences for work (Beblo and Görges 2018), and changed gender norms (Bauernschuster and Rainer 2011; Campa and Serafinelli 2018) and preferences more generally (e. g., Alesina and Fuchs-Schündeln 2007). ${ }^{12}$

\footnotetext{
11 A parental leave reform in 2007 entitled mothers to up to 12 months of much more generous parental leave benefits tied to their pre-birth wages, moving Germany's parental leave system closer to that of the former GDR (see for instance, Raute 2019). In the empirical analysis, we focus on mothers who gave birth before the reform came into effect.

12 Lippmann, Georgieff, and Senik (2019) show that the male breadwinner norm as identified by Bertrand, Kamenica, and Pan (2015) is pronounced in West Germany, but does not exist in East Germany.
} 
Figure 2

Cross-Country Differences in Gender Norms (European Values Study)

Part A: Germany as a whole

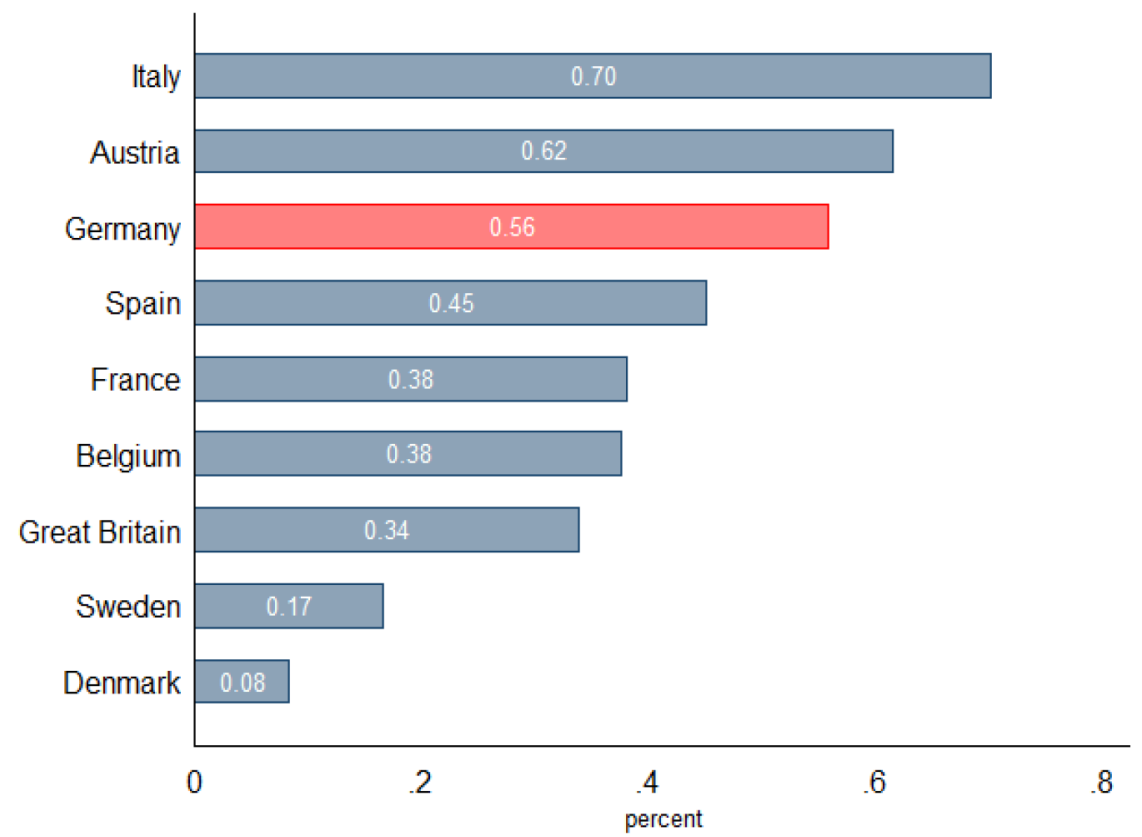

Part B: West vs East Germany

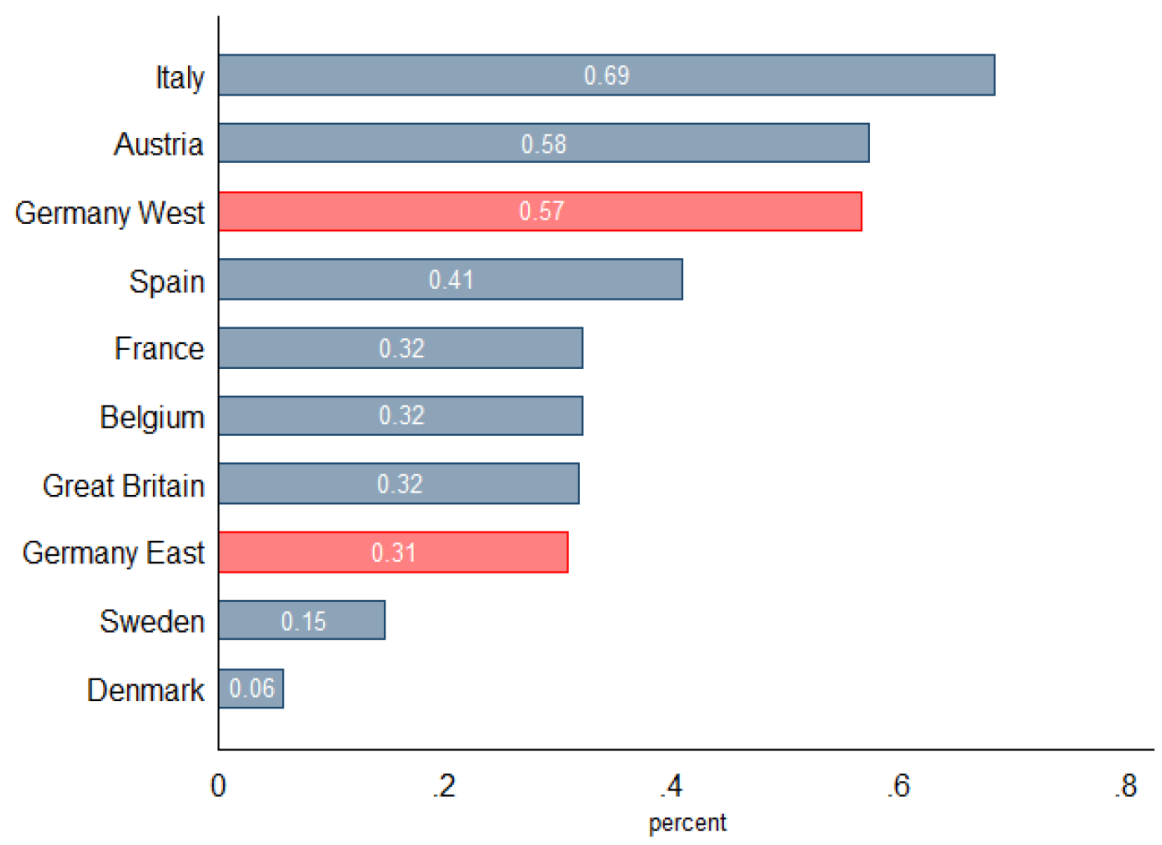

Notes: The figures show the share of respondents agreeing to the EVS survey question d061 "A pre-school child suffers when his or her mother works" in 2008 for selected countries. We recoded both original answers "agree" and "strongly agree" as "agree". In Part A, we show the share of men and women agreeing for the whole of Germany, while in Part B we split up Germany into former West and former East Germany.

Source: European Values Study Longitudinal Data File 1981-2008 (EVS 2014). 


\section{Data and Descriptive Evidence}

\subsection{Data Description and Sample Selection}

Our data are drawn from social security records provided by the Institute for Employment Research (IAB) in Nuremberg, and are available for the years 1975 to 2010 for West Germany and 1992 to 2010 for East Germany. We do not use data post 2010 because a change in the reporting system in 2011 led to a structural break and consequent missing data for a number of key variables (e. g., full-time work) in the social security data, which are crucial for studying maternal labor supply. The data source comprises the complete work histories, including length of leave due to childbirth, for every woman and man covered by the social security system, with the exception of civil servants, the selfemployed, and military personnel.

From this data source, we select a random sample of 50 percent of all women with German citizenship who were born between 1946 and 1994 in order to construct the career histories of first-time mothers who were between the ages 18 and 40 at the birth of their first child and who took maternity leave between 1986 and 2006. In addition, we use the full population data to calculate, based on spells that refer to June 30 in a given year, the extent of a woman's East German colleagues and neighbors, as well as firm-level variables such as average wage or number of employees in the firm.

Our data offer a number of key advantages. First off, the large sample size allows to both investigate mothers' labor market outcomes around child birth (a key driver of the gender gap), while simultaneously focusing on mothers within the same cross-border local labor market, or those who migrated from one part of Germany to the other. Such a detailed analysis would simply not be possible using the much smaller German Socio-Economic Panel or the cross-sectional German Microcensus. A second advantage is the precise measurement of the mother's labor force status, part-time work, occupation, education, and (daily) wages (measured in 2010 EUR prices) before and after childbirth, allowing us to pinpoint the exact month the mother returns to work after childbirth. Identifiers for single production sites (referred to as "firms" for simplicity) allow to not only compare the pre- and post-birth outcomes of mothers from East and West Germany employed in the same firm, but also to construct West German mothers' exposure to East German colleagues.

As our data do not contain direct information on children, we focus on first-time mothers who were employed prior to giving birth and hence are required by law to request maternity leave. ${ }^{13}$ Neither does this data record the place of birth. We therefore primarily classify mothers as of West or East German origin based on their first place of work. ${ }^{14}$ This is a very good proxy for the German context, where the large majority of women began their working life with a firm-based apprenticeship train-

\footnotetext{
13 Mothers in Germany are prohibited from working in the first eight weeks after birth (Mutterschutz) and must therefore take maternity leave. Own calculations based on data from the German Socio-Economic Panel suggest that 82 percent of all first-time mothers between 1990 and 2010 were working in the year prior to giving birth. Unfortunately, the social security records do not explicitly distinguish between maternity leave and other leaves of absence, such as sickness. Schönberg (2009) shows, however, that after imposing appropriate restrictions, at least 90 percent of authorized absences in the data are for maternity reasons (see also Müller and Strauch (2017)). We follow suit and impose these same sample restrictions (Schönberg 2009).

14 Heise and Porzio (2019) show, using GSOEP data, that the region of a worker's first employment corresponds to their birth region in 88-92 percent of cases for East Germans and 99 percent of cases for West Germans.
} 
ing (74 percent of mothers) close to their hometown. ${ }^{15}$ Such an approximation may nevertheless erroneously classify some East Germans as West Germans if they migrated to West Germany prior to 1992 (the year social security records become available for East Germany). In order to avoid such misclassification, we develop an imputation method based on their age and educational attainment when they are first observed in the West German social security data (between 1989 and 1992) see the Appendix for details. Our results are also robust to alternative imputation rules designed for this purpose. (Müller and Strauch 2017)

Our empirical analysis focuses primarily on mothers' labor market attachment after childbirth. We distinguish between three different employment statuses: overall employment which also included so-called "marginal employment" (i. e., below an income level of 400 EUR per month between 2003 until 2013); regular employment, defined as full- or part-time work, excluding marginal employment; and full-time work characterized as working at least 35 hours per week. ${ }^{16}$ Indicator variables for whether the mother "downgraded" to an occupation with a lower average male wage after birth, and for whether she continues to work for the same pre-birth employer (used primarily in Section 6) complete our career-related outcome variables. The latter outcomes are defined for the entire sample independent of whether the woman returned to work; non-working mothers are coded as having downgraded, and as not working for the same pre-birth employer, respectively.

\subsection{Descriptive Evidence}

To provide a first descriptive overview of our data, Part A of Figure 3 contrasts the return-to-work behavior (defined as the first time that a mother works at least 8 hours per week for a consecutive period of two months) of East and West German mothers who gave birth in 2003, 13 years after German reunification. These mothers are entitled to three years of job protection, and two years of means-tested leave benefits of up to 300 Euros per month, regardless of whether they give birth in East or West Germany. We observe that the share of West German mothers who return to work increases fairly smoothly with month after childbirth up until a larger spike around 36 months after childbirth, when the job protection period ends. The return behavior for East German women mirrors that of West Germans up until 12 months after birth, but then diverges. Most strikingly, a sizable share of East German mothers returns to work exactly 12 months after birth, or the end of the job protection and benefit period granted in the former GDR. Thus, 13 years after reunification, a substantial share of East German mothers still behave in accordance with the social and institutional norms of the former GDR, even though the current parental leave system provides them with limited financial incentives to do so. Furthermore, East German mothers appear to respond more strongly to parental leave benefits than do West German mothers, as about 10 percent of mothers return to work precisely 24 months after giving birth, or when the current regular parental leave benefit period ends. By the time the child is seven years old and has entered primary school, East German

\footnotetext{
15 In 2016, only 13.9 percent of youth applied for apprenticeship training further than 50 km away from their primary residence (Bundesinstitut für Berufsbildung 2018). Drawing on a 2013 survey on business and economics studies from six universities in northern and central Germany, Weisser (2019) shows that students on average attended university within $71 \mathrm{~km}$ of their homes and that a quarter stay within a radius of $25 \mathrm{~km}$. Along similar lines, using data from the GSOEP, Busch and Weigert (2010, 568) document that even ten years after graduation, more than 70 percent of university graduates still live in the state where they completed their studies.

16 Marginal employment only gained popularity after substantial reforms in 1999, and then particularly in 2003 . This status is recorded in our data from 1999 onwards.
} 
mothers are nearly 20 percentage points more likely to have returned to work than West German mothers.

Figure 3

Return-to-Work Behavior and Child Penalties: East versus West German Mothers

Part A: Share of mothers who have returned to work after childbirth

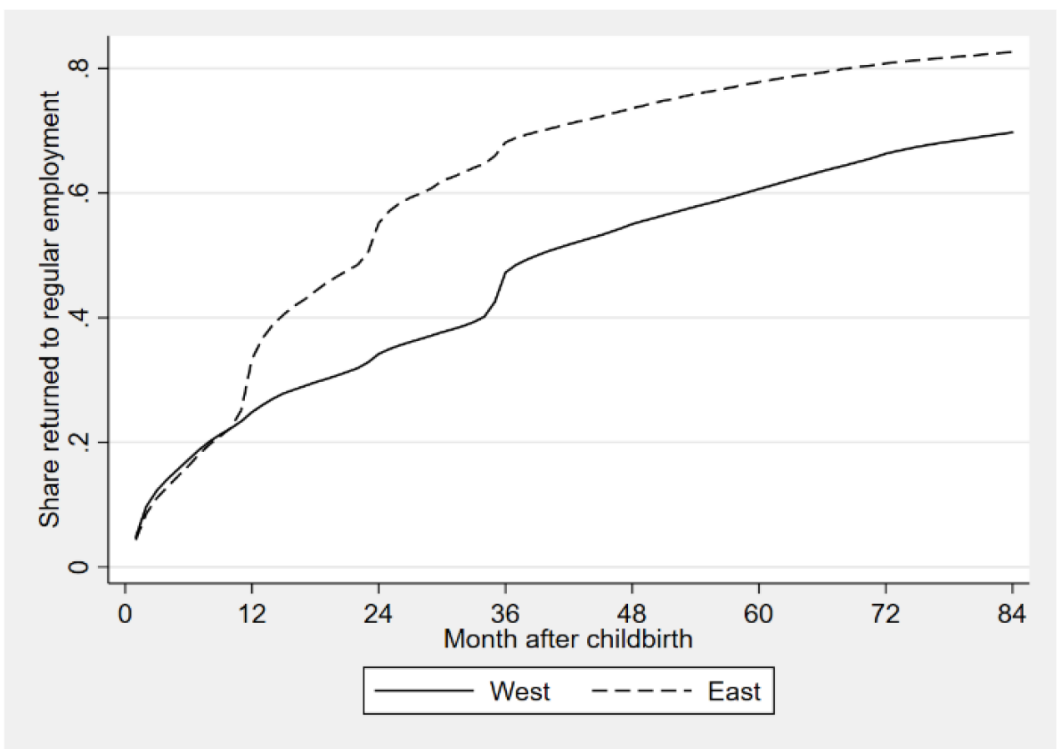

Part B: Child penalties pre and post childbirth

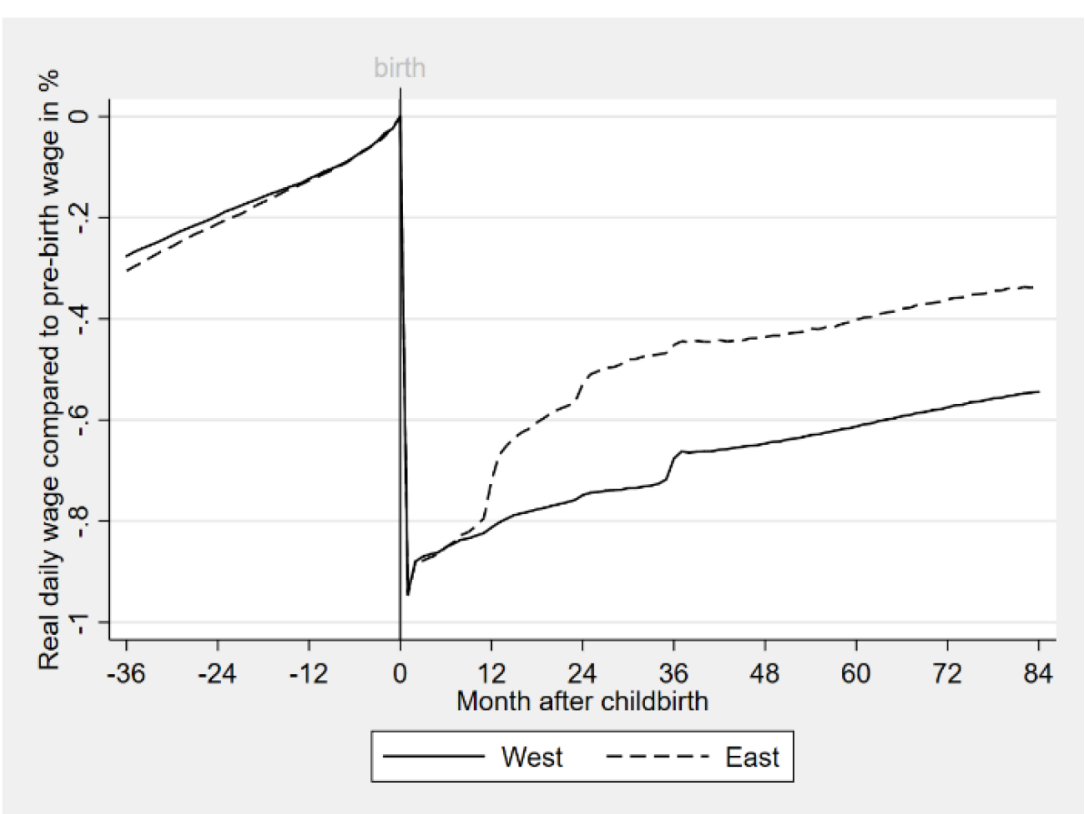

Notes: The figures show return-to-work behavior (Part A) and child penalties (Part B) after childbirth for East and West German women who took maternity leave in 2003. Part A depicts the share of women who have returned to regular employment (excluding marginal employment) by month t up until 7 years after childbirth. Part B displays the child penalty, defined as daily earnings (set to zero if the mother is not employed) in a given month relative to her daily earnings one month before childbirth, 3 years before up until 7 years after childbirth.

Source: Social Security Records, first-time mothers who signed up for maternity leave in 2003. 
Part B of Figure 3 shows the evolution of earnings of West and East German mothers around childbirth relative to those one month prior to parental leave. We compute the "child penalty" as the difference between the mother's earnings in a given month after childbirth (where earnings are set to 0 if the mother is not working) and those right before childbirth, and divide by her pre-birth earnings. While child penalties are sizable for both West and East German mothers in the medium-run, East German mothers recover around 70 percent of their pre-birth earnings by the time the child is seven - similar in magnitude to mothers in the US and Sweden (Kleven et al. 2019). West German mothers, in contrast, recover only around 45 percent of their pre-birth earnings seven years after birth. Our own calculations suggest that in both East and West Germany, child penalties are primarily driven by a reduction in the propensity to work and a shift from full-time to part-time work after childbirth. Indeed, for this reason we focus on mothers' post-birth labor market attachment as a key outcome variable.

The descriptive evidence in Figure 3 clearly demonstrates that East German mothers return to work earlier and suffer smaller earnings losses than do West German mothers-despite the fact that the institutional setting (e. g., the maternity leave legislation or the tax system, both key determinants of women's post-birth labor market choices) is the same in East and West Germany. While these differences may be driven by cultural distinctions between East and West, they may also be influenced by other factors, including differences in local labor market conditions such as the higher unemployment rate in East Germany (18.7 percent compared to 9.9 percent in West Germany in 2005), childcare availability, or pre-birth characteristics.

Our goals are to first use the unique setting of the division and subsequent reunification of the country to isolate the overall effects of culture on women's post-birth career paths from potential alternative factors and then second, differentiate between the importance of the culture the woman was exposed to as a child versus that she encounters in adulthood. It should be noted that while differences in local labor market opportunities are a clear confounding factor, those relative to childcare availability and pre-birth characteristics may instead be viewed as consequences of the cultural divergence between East and West Germany. If few mothers intend to work when their children are young, the supply of childcare centers will be low. Women may invest more in education and choose more demanding occupations prior to giving birth if they expect to return to the labor market quickly afterwards. Existing evidence, however, suggests that women underestimate the large future employment effects of children when making human capital decisions (Kuziemko et al. 2018), and that children primarily affect women's careers after birth (Adda, Dustmann and Stevens 2017; Angelov, Johansson, and Lindahl 2016; Kleven, Landais, and Søgaard 2019). ${ }^{17}$ Given such evidence, we condition on a woman's pre-birth work history in our baseline specification, a choice that does not impact our estimates.

In the next four sections, we delve more specifically into the four empirical strategies described above, designed to disentangle the effects of childhood and current culture from other potential drivers of women's post-birth career choices.

\footnotetext{
17 Adda, Dustmann, and Stevens (2017) estimate that while anticipated fertility does affect choice of occupation at a young age - women would be 5 percent more likely to work in abstract task occupations - the contribution of occupational choice to the overall career costs of children appears relatively small (around 4.5 percent).
} 


\section{The Legacy of East German Culture: Evidence from the Former Border}

\subsection{Empirical Specification}

In a first step, we compare, building on Eugster et al. (2011, 2017), Steinhauer (2018), and Campa and Serafinelli (2018), mothers in neighboring municipalities located right at the former Inner German Border. Rather than applying a spatial regression discontinuity strategy as in the existing literature, we adopt a tighter design and restrict the sample to mothers within the five integrated cross-border local labor markets or commuting zones, depicted in Appendix Figure A1 and defined as municipalities connected through high commuter flows (Kosfeld and Werner 2012). ${ }^{18}$ We focus on first-time mothers who gave birth between 2003 and 2006, 13 to 16 years after German reunification. These women were born on average in 1975 and thus spent their childhoods under two very different regimes. However, they then made important education and labor market decisions after reunification under a common politico-economic system. By the time they make their post-birth career choices, economic integration was more advanced within these local labor markets compared to areas further away from the border, with ample scope for social interaction and economic exchange.

We estimate regressions of the following type separately at different distances from childbirth (indexed by the superscript $k$ ), pooling first-time mothers who gave birth and took maternity leave between 2003 and 2006:

$$
Y_{i l t}^{k}=\beta_{1}^{k} \text { East }_{i}+\theta_{l t}^{k}+x_{i t}^{\prime} \gamma^{k}+v_{i l t}^{k}
$$

where the subscript $i$ indexes the mother and the subscripts $/$ and $t$ index the local labor market where, and year when, she gave birth. $Y_{i l t}^{k}$ denotes the outcome of interest, for instance the probability that the mother is employed 1 or 4 years after childbirth; East ${ }_{i}$ is an indicator equal to 1 if a woman is East German; $\theta_{l t}$ are year of birth-local labor market (at the time of birth) fixed effects; $x_{i l t}$ denote a mother's pre-birth characteristics; and $v_{i l t}^{k}$ is an error term. We consider two sets of prebirth control variables. "Control set I" includes the mother's age, education, occupation, wage, and full-time status at birth; "control set II" additionally includes mothers' work history variables three years prior to childbirth, where we distinguish between full-time work and regular employment. We cluster standard errors at the municipality of work at birth.

The parameter of interest, $\beta_{1}^{k}$, captures the differences in post-birth career outcomes between women differently socialized in East and West Germany, but who gave birth in the same economically integrated local labor market in the same year. Notably, the two groups differ not only in terms of the culture they were exposed to as children and teenagers, but also relative to their peers in adulthood, both in their neighborhood and the workplace. For the typical West German mother in a cross-border local labor market, 15 percent of her colleagues and 19 percent of her neighbors (defined as employees who reside in the same municipality as the mother) are from East Germany, compared to 77 percent and 83 percent respectively for the typical East German mother. This strategy therefore identifies a combined effect of childhood and current culture on mothers' post-birth

18 Within a local labor market, commuting from one point to another within the zone takes a maximum of 45 to 60 minutes, depending on the local labor market (Kosfeld and Werner 2012, 51). 
career paths. Note that the differences between East and West Germans in the current cultural environment are smaller in these integrated local labor markets, as opposed to more remote regions further away from the former border, a consequence of the greater social interactions between East and West Germans through commuting. Indeed, whereas in the cross-border local labor markets 15 percent of the colleagues of West German mothers are East German, exposure to East German colleagues in more remote West German areas is just 5 percent.

This approach also limits the importance of potential confounding drivers of maternal career choices. First, within these cross-border integrated local labor markets, East and West German women have access to the same local labor market opportunities. Second, we control for potential differences between East and West German mothers in pre-childbirth labor market investments, comparing East and West German mothers with the same observable characteristics prior to having a child. Since these differences may in part stem from cultural differences, we also report results that do not condition on mothers' pre-birth characteristics. While differences in post-birth employment outcomes between East and West German mothers may in principle arise from distinctions in childcare availability (which may themselves be a result of cultural differences), this effect should be minimal once the child is 4 years old. That is, when childcare is widely available and attendance is also high in the West German areas of the cross-border local labor markets.

\subsection{Results}

Baseline Results. In Table 1, we first show the raw and conditional East-West German gap in postbirth employment and career outcomes for Germany as a whole (excluding the five cross-border local labor markets) when the child is one and four years old (columns (1) and (2) in Panels A and B). Gaps are sizeable for all outcomes. For example, conditional on mothers' characteristics prior to childbirth (as in control set I, column (2)), East German mothers are 17 percentage points more likely to be regularly employed (excluding marginal employment with very low weekly working hours) and 13.1 percentage points more likely to be employed full-time four years after birth than West German mothers.

When we compare East and West mothers within the same cross-border integrated local labor markets (columns (3) to (6)), the East-West gap narrows, likely due to greater social interactions between East and West Germans and larger economic integration in these areas. Point estimates slightly increase in magnitude when we condition on mothers' pre-birth characteristics and work histories in columns (4) and (5), indicating that the East-West gap is not explained by larger career investments made by East German mothers prior to childbirth. According to specification (4) in Panel A, East German mothers are 11.5 percentage points or-if evaluated against the 40.1 percent baseline employment probability of West German mothers-29 percent more likely to be employed (excluding marginal employment) four years after childbirth. This gap that is somewhat larger than the employment gap of 5-10 percentage points between German- and French-speaking mothers along the Franco-German language border in Switzerland found by Steinhauer (2018). The EastWest employment gap including marginal employment as well as that of the probability of working full-time four years after childbirth are somewhat smaller in (absolute) magnitude: 8.03 and 8.79 percentage points. These results suggest that West German mothers prefer marginal employment relationships with very short hours, whereas East German mothers favor full-time work. East German mothers are 10.8 percentage points less likely to downgrade to a lower paying occupation 
Table 1

Differences in Post-Birth Employment Outcomes between East and West German Mothers: Overall Germany vs Integrated Cross-Border Local Labor Markets

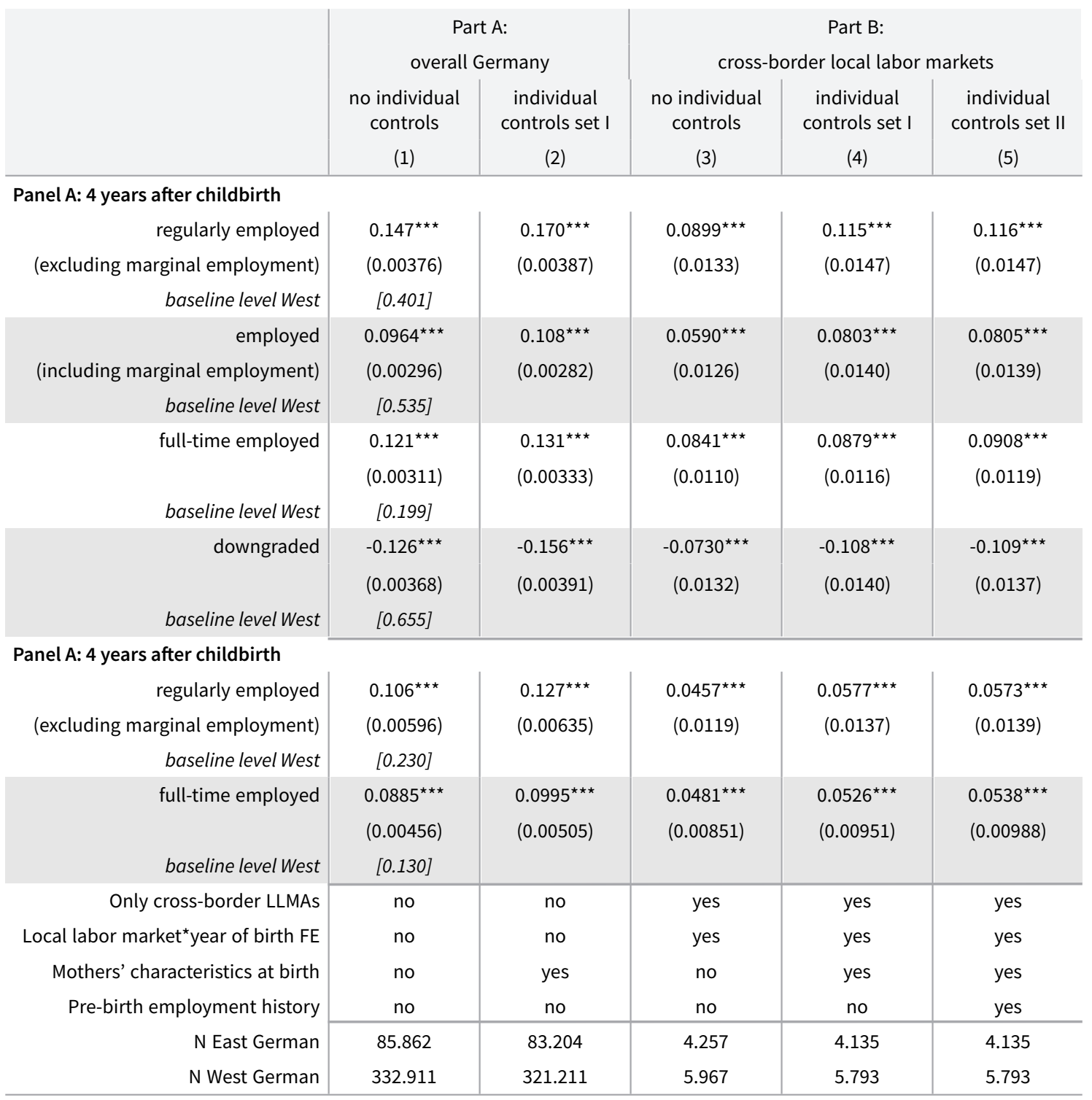

Notes: The table reports coefficient estimates of the East dummy in equation (1), estimated for Germany as a whole (excluding the five cross-border local labor markets) in columns (1) and (2) and restricted to the five cross-border local labor markets in columns (3) to (6). In columns (1) and (3), we only control for local labor market by year of birth fixed effects. In columns (2) and (4), we add individual control variables at the time of birth (control set I [mother's age, education, occupation (3-digit), wage and full-time status at birth]). Regressions in column (5) additionally include mothers' work history variables in the three years prior to birth (control set II [three indicator variables each for full-time employment and regular employment in three years prior to childbirth]). We additionally report baseline means for West German mothers in the entire West German labor market for each of our outcomes in column (1). Standard errors clustered on the local labor market level of the place of work when taking maternity leave are reported in parentheses. * statistically significant at the 0.10 level, ${ }^{\star \star}$ at the 0.05 level, ${ }^{\star \star \star}$ at the 0.01 level.

Source: Social Security Records, first-time mothers who signed up for maternity leave in 2003-2006 in Germany as a whole (excluding the five integrated cross-border local labor markets, Part A) and in the five integrated cross-border local labor markets (Part B).

four years after birth; a gap that is largely driven by West German mothers working less than East German mothers.

The East-West employment gaps are already apparent by the child's first birthday, when the job protection and maternity benefit period would have ended in the former GDR (Panel B). While smaller 
in absolute magnitude than the effects four years after childbirth, they are of similar magnitude if evaluated against the baseline employment probability of West German mothers.

East-West Gap in Employment by Time up to and since Childbirth. We investigate the evolution of the East-West gap in mothers' regular employment (excluding marginal employment) around childbirth in greater detail in Figure 4. Specifically, we plot coefficients of the East ${ }_{i}$ dummy in equation (1) estimated separately for each month starting 36 months prior, and up to 84 months after childbirth, controlling for mothers' pre-birth characteristics at the time of birth (control set I, as in column (4) of Table 1). ${ }^{19}$ Prior to childbirth, as well as up until one year afterwards, West German mothers are about equally likely (or unlikely) to be employed as East German mothers. The EastWest gap starts to widen at this point, when a large share of East German mothers returns to the labor market, conforming to the (no longer existent) parental leave legislation of the former GDR. This divide increases in size up until three years after birth when the job protection period ends and a substantial share of West German mothers return to the labor market, and declines thereafter. Yet even seven years after birth, East German mothers are still about 6.6 percentage points more likely to have returned to the labor market than their West German counterparts.

Figure 4

The East-West Gaps in Maternal Employment by Time To and Since Childbirth: Integrated Cross-Border Labor Markets

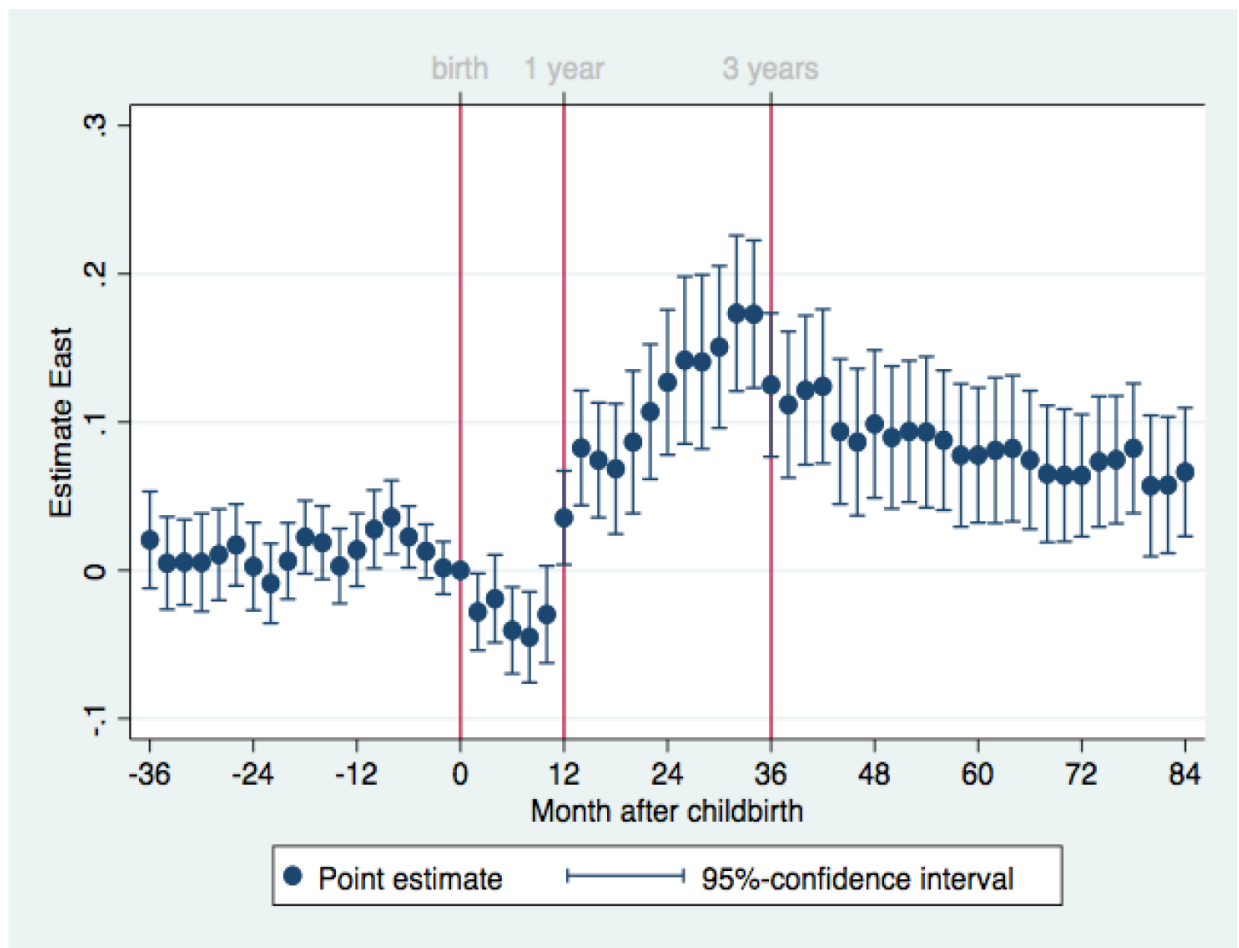

Notes: The figure shows the East-West gaps in mothers' regular employment (excluding marginal employment) around childbirth for women who went on maternity in 2003 in one of the five integrated cross-border local labor markets. It plots the estimated coefficients and associated $95 \%$ confidence intervals of the East dummy variable in equation (1) estimated separately for each month starting 36 months prior to until 84 months after childbirth. We control for local labor market (at the time of birth) fixed effects and mothers' pre-birth characteristics at the time of birth (control set I [mother's age, education, occupation (3-digit), wage and full-time status at birth] as in column (4) of Table 1).

Source: Social Security Records, five integrated cross-border local labor markets, first-time mothers who signed up for maternity leave in 2003.

19 We restrict the sample to women who took leave in 2003 in order to depict differences in return behavior up to 84 months after giving birth in analogy to descriptive Figure 3. 


\section{How Persistent is Childhood Culture? Evidence from Migrants}

The previous section establishes that sizable differences remain between East and West German women within the same integrated cross-border labor markets even 13-16 years after German reunification. But which aspect of culture is more important, that which the woman was exposed to as a child, or the culture which she encounters as an adult, when becoming a mother? To provide a better understanding of the importance of each aspect of culture, we focus on East and West Germans who moved across the former border to a culture different from that of their childhoods. Do these women accordingly adjust to the new culture, or do they maintain the values and beliefs of their childhood environment? And is adaptation to a new culture possibly asymmetric, depending on whether a woman moves to a more gender egalitarian or a more gender traditional culture?

\subsection{Empirical Specification}

To address these questions, we build on the epidemiological approach (e. g., Fernández 2007; Giuliano 2007; Fernández and Fogli 2009) and compare the post-birth career choices of East and West German "migrant" and "native" mothers who gave birth in the same West (or East) German local labor market, or were even employed in the same firm. We estimate regressions of the following type separately for different points in time after childbirth (indexed by the superscript $k$ ), for firsttime mothers who gave birth between 2003 and 2006 and hence made important education and labor market decision after reunification:

$$
Y_{i l f t}^{k}=\beta_{1}^{k} E_{a s t_{i}}+\theta_{l t}^{k}+\delta_{f}^{k}+x_{i t}^{\prime} \gamma^{k}+v_{i l f t}^{k}
$$

where the subscript $i$ indexes the mother and the subscripts $l, f$, and $t$ index the local labor market and firm where, and the year when, she gave birth. East $t_{i}$ is an indicator equal to 1 if the mother originates from East Germany, $\theta_{l t}^{k}$ are year of birth-local labor market fixed effects (at the time of birth), and $\delta_{f}^{k}$ fixed effects that refer to the mother's pre-birth employer. To capture possibly asymmetric adjustments to a more gender traditional versus egalitarian culture, we estimate equation (2) on two samples: East German migrants and West German natives in the West German labor market, and West German migrants and East German natives in the East German labor market. Standard errors are clustered at the level of the local labor market at birth.

The parameter of interest, $\beta_{1}^{k}$, primarily captures the persistent impact of childhood culture on mothers' post-birth career choices. ${ }^{20}$ Conditioning on local labor market effects at time of birth eliminates differences in labor market opportunities and access to childcare between migrants and natives. It further ensures that immigrants and natives share a similar network of neighbors. In our sample, 5.6 percent of neighbors (defined as employees who reside in the same municipality as the

\footnotetext{
20 East (West) German migrants may themselves induce West (East) German mothers to increase (reduce) their labor supply after childbirth, which would lead us to underestimate the impact of childhood culture on maternal employment. Our findings in Section 7 show that for the typical West German mother, exposure to East German migrants was too small to trigger measurable increases in their own labor supply. The bias from spillovers from the minority to the majority culture in this full immersion setting is therefore likely to be small.
} 
mother) of the typical East German migrant in West Germany are East German, compared to 5 percent for the typical West German native, while 93.8 percent and 95 percent of neighbors of the typical West German migrant and East German native are East German, respectively (see also Panel B of Appendix Table A1). These numbers illustrate that both East and West German migrants are a clear minority in the local labor markets they respectively moved to and are nearly fully immersed in the majority native culture. By comparing migrant and native mothers who gave birth in the same firm, we also hold constant their work colleagues at the time of birth.

A potential concern is that migrant and "native" mothers not only differ with respect to the culture they grew up in, but also in other aspects. Panel A of Appendix Table A1 shows that East German migrants are somewhat older and West German migrants are somewhat younger at the birth of their first child compared to East and West German "stayers." East German migrants are slightly positively selected in terms of their education, pre-birth wage, and pre-birth full-time work status relative to West German stayers, as are West German migrants relative to East German stayers. We control for these small differences in pre-birth characteristics (control set I) as well as potential differences in labor market trajectories three years prior to birth in our estimation (control set II). Migrants may differ from stayers in ways not captured by our control variables. To rule out this concern, we report additional robustness checks, including a comparison between cross-border migrants and internal (West-West or East-East) migrants, in Tables 3 and 5.

\subsection{East German Migrants in West Germany}

Baseline Estimates. We first consider East German migrants in the West German labor market. In this sample, the coefficient $\beta_{1}^{k}$ captures the persistent effects of having grown up in a more gender egalitarian culture as a child and teenager on behavior as an adult when immersed in a more gender traditional current culture. The findings in Table 2 point toward substantial East-West gaps in employment outcomes both four (Panel A) and one (Panel B) year after childbirth. For example, in our preferred specification, which conditions on local labor market by year of birth fixed effects, fixed firm effects that refer to the pre-birth employer, pre-birth characteristics, and work trajectories (control set II) in column (4), the East-West gaps four years after birth in regular and overall employment (excluding and including marginal employment) and full-time employment are 7.9, 6.22 , and 5.09 percentage points respectively, while the East-West gap in downgrading is 6.93 percentage points (and hence largely driven by the East-West gap in employment). It should be noted that controlling for women's pre-birth characteristics (control set I) and labor market trajectories (control set II) only slightly reduces the raw East-West gaps, suggesting that differential labor market investments prior to childbirth cannot account for these observed gaps (compare columns (1), (2), and (3)). Conditioning on pre-birth employer fixed effects in column (4), thus contrasting East and West German women who give birth within the same firm, likewise has only a small impact on the estimated East-West gaps. That said, adding firm fixed effects substantially improves the explanatory power of the regression models (the R-squared increases from about 0.04 to 0.29 ). ${ }^{21}$ Hence, East Germans do not systematically sort into West German firms where women are generally more likely to remain employed after birth. Moreover, East-West gaps are of similar magnitude when we

21 This finding is in line with Kleven, Landais, and Søgaard (2019) and Hotz, Johansson, and Karimi (2017) who show that women's post-birth career decisions vary widely across firms, even within the same industry. 
compare East German migrants who worked in West Germany for at least six years before giving birth and have thus been exposed to the more traditional culture in adulthood for a longer period of time, with West German mothers with at least six years of work experience prior to childbirth (column (5)).

Table 2

Differences in Post-Birth Employment Outcomes between East and West German Mothers in West Germany

\begin{tabular}{|c|c|c|c|c|c|}
\hline & $\begin{array}{c}\begin{array}{c}\text { same local labor } \\
\text { market }\end{array} \\
\text { (1) }\end{array}$ & $\begin{array}{c}\text { same local labor } \\
\text { market, controls } \\
\text { set I } \\
\text { (2) }\end{array}$ & $\begin{array}{c}\text { same local labor } \\
\text { market, controls } \\
\text { set II } \\
\text { (3) }\end{array}$ & $\begin{array}{l}\text { same firm, } \\
\text { controls set II } \\
\text { (4) }\end{array}$ & $\begin{array}{l}\text { same firm, } \\
\text { controls set II, } \\
\text { long-term } \\
\text { migrants } \\
\text { (5) }\end{array}$ \\
\hline \multicolumn{6}{|l|}{ Panel A: 4 years after childbirth } \\
\hline regularly employed & $0.101^{\star \star \star}$ & $0.0857^{\star \star \star}$ & $0.0849^{\star \star \star}$ & $0.0792^{\star \star \star}$ & $0.0776^{\star \star \star}$ \\
\hline (excluding marginal employment) & $(0.00671)$ & $(0.00717)$ & $(0.00700)$ & $(0.00821)$ & $(0.0120)$ \\
\hline employed & $0.0795^{\star \star \star}$ & $0.0600^{\star \star \star}$ & $0.0587^{\star \star \star}$ & $0.0622^{\star \star \star}$ & $0.0671^{\star \star \star}$ \\
\hline (including marginal employment) & $(0.00679)$ & $(0.00692)$ & $(0.00650)$ & $(0.00656)$ & $(0.0117)$ \\
\hline \multirow[t]{2}{*}{ full-time employed } & $0.0589^{\star \star \star}$ & $0.0570^{\star \star \star}$ & $0.0568^{\star \star \star}$ & $0.0509^{\star \star \star}$ & $0.0615^{\star \star \star}$ \\
\hline & $(0.00442)$ & $(0.00430)$ & $(0.00435)$ & $(0.00645)$ & $(0.00949)$ \\
\hline \multirow[t]{2}{*}{ downgraded } & $-0.0912^{\star \star \star}$ & $-0.0709^{\star \star \star}$ & $-0.0694^{\star \star \star}$ & $-0.0693^{\star \star \star}$ & $-0.0721^{\star \star \star}$ \\
\hline & $(0.00746)$ & $(0.00735)$ & $(0.00694)$ & $(0.00865)$ & $(0.0118)$ \\
\hline \multicolumn{6}{|l|}{ Panel B: 1 year after childbirth } \\
\hline regularly employed & $0.0482^{\star \star \star}$ & $0.0376^{\star \star \star}$ & $0.0384^{\star \star \star}$ & $0.0366^{\star \star \star}$ & $0.0500^{\star \star \star}$ \\
\hline (excluding marginal employment) & $(0.00503)$ & $(0.00576)$ & $(0.00594)$ & $(0.00706)$ & $(0.00976)$ \\
\hline \multirow[t]{2}{*}{ full-time employed } & $0.0389^{\star \star \star}$ & $0.0303^{\star \star \star}$ & $0.0306^{\star \star \star}$ & $0.0264^{\star \star \star}$ & $0.0360^{\star \star \star}$ \\
\hline & $(0.00496)$ & $(0.00521)$ & $(0.00531)$ & $(0.00721)$ & $(0.0106)$ \\
\hline R-squared & 0.009 & 0.042 & 0.043 & 0.289 & 0.304 \\
\hline local labor market ${ }^{\star}$ year of birth FE & yes & yes & yes & yes & yes \\
\hline Firm FE & no & no & no & yes & yes \\
\hline Mothers' characteristics at birth & no & yes & yes & yes & yes \\
\hline Pre-birth employment history & no & no & yes & yes & yes \\
\hline N East German migrants & 14.959 & 14.789 & 14.789 & 9.352 & 3.076 \\
\hline N West German natives & 322.803 & 311.717 & 311.717 & 194.269 & 108.364 \\
\hline
\end{tabular}

Notes: The table reports coefficient estimates of the East dummy in regression equation (2), estimated on a sample of East German first-time who migrated from East to West Germany prior to giving birth and West German "stayers". In column (1), we control only for local labor market by year of birth fixed effects. In column (2), we add mothers' control variables at the time of birth (control set I [mother's age, education, occupation (3-digit), wage and full-time status at birth]). In column (3), we additionally include mothers' employment history variables in the three years prior to birth as control variables (control set II [three indicator variables each for full-time employment and regular employment in three years prior to childbirth]). In column (4), we add firm (at the time of birth) fixed effects. In column (5), we restrict the sample to East German migrants who have been in West Germany for at least 6 years prior to giving birth and West German stayers with at least six years of labor market experience prior to giving birth. The R squared refers to our main outcome variable, regular employment (excluding marginal employment) four years after childbirth. Standard errors clustered on the local labor market level of the place of work when taking maternity leave are reported in parentheses. * statistically significant at the 0.10 level, ${ }^{\star \star}$ at the 0.05 level, ${ }^{* \star \star}$ at the 0.01 level.

Source: Social Security Records, first time mothers who signed up for maternity leave in 2003-2006 in West Germany.

In line with the findings in Table 1 and Figure 4 for the cross-border approach, the East-West gap is already evident one year after birth, when the job protection and maternity benefit period would have ended in the former GDR (Panel B).

Robustness Checks. A remaining concern is that the East-West gaps presented in Table 2 not only reflect differences in childhood culture, but also differences in unobserved characteristics. For 
example, migrants may generally be less risk-adverse or more career-oriented than non-migrants. To rule out this issue, we first contrast East German migrants with West Germans who migrated at least the average distance as the aforementioned East German migrants (ca. $280 \mathrm{~km}$ ), but did so internally within West Germany. East-West gaps in Table 3 increase in magnitude relative to our baseline estimates that condition on local labor market by year of birth fixed effects and pre-birth employer fixed effects, in addition to mothers' pre-birth characteristics and work trajectories (as in column (4) of Table 2; compare columns (1) and (3) of Table 3). Next, we restrict the sample to West German firms operating in the five integrated cross-border local labor markets. East Germans in these firms are primarily commuters and thus face substantially lower moving costs than crossborder migrants, thus limiting the potential concern of differential selection. ${ }^{22}$ Estimates in column (4) of Table 3 are similar in size to our baseline estimates reported in column (1).

Evidence based on the German Socio-Economic Panel (GSOEP) shows that East German migrant mothers are considerably more likely to have an East German partner-who therefore also grew up in the more gender egalitarian environment-than West German stayers (44 percent vs. 2 percent; Panel D of Appendix Table A1). The effect of childhood culture of the mother may therefore operate in part through the childhood culture of her partner (see Fernández, Fogli, and Olivetti 2004; Fernández and Fogli 2009; Blau 2015). While the net earnings of partners of East German migrant mothers are 6.9 percent or about 140 Euros per month lower than those of partners of West German mothers (Panel D of Appendix Table A1), simple calculations suggest that this difference is not large enough to account for East-West gaps in post-birth employment outcomes. ${ }^{23}$

Overall, these findings suggest that childhood culture has a persistent effect on women's post-birth career choices, even when they have been fully immersed in a more traditional majority culture for a significant period of time. The East-West gap in regular employment four years after childbirth of about 8 percentage points is comparable to findings for the US on the effect of having had a working mother during high school (Olivetti, Patacchini, and Zenou, forthcoming) or the difference, in the US and UK, in employment between college-educated and non-college-educated young mothers (Kuziemko et al. 2018). ${ }^{24}$ It should be noted that employment gaps between East German migrants and West German stayers are somewhat smaller in magnitude than East-West gaps in the crossborder local labor market (7.92 vs. 11.6 percentage points), possibly due to larger differences in the current cultural environment between East and West Germans in the cross-border local labor market. At face value, a comparison of the East-West employment gap in the cross-border local labor market (which captures a combination of childhood and current culture) with the gap in West Germany (which predominantly measures differences in childhood culture) suggests that for women who grew up in a more gender egalitarian culture, childhood culture is about twice as important as the current culture $(68 \%(0.0792 / 0.116)$ vs. $32 \%)$ in shaping their post-birth employment decisions as mothers.

\footnotetext{
22 To obtain a sufficiently large sample size, we include East and West Germans who gave birth between 1997 and 2006 (as opposed to between 2003 and 2006, in our baseline specification).

23 Our own calculations using the GSOEP for the years 1990 to 2010 show only a weak correlation between employment of firsttime mothers in the first four years after childbirth and spousal income. Controlling for mothers' education, age, and the child's age, an increase in spousal gross income of 1000 EUR is associated with a decrease in maternal employment of about 1 percentage point. This fairly low responsiveness of maternal employment to spousal income is in line with findings for the US by Blau and Kahn (2007), who document that cross wage elasticities of married women declined substantially between 1980-2000 to levels of around -.11 to -0.13 in 2000.

24 Papers using the epidemiological approach typically examine the effects on working hours (e. g. Fernández 2007; Fernández and Fogli 2009). These papers therefore capture both the extensive and intensive margin of labor supply and are difficult to compare with our estimates.
} 
Table 3

Differences in Post-Birth Employment Outcomes between East and West German Mothers in West Germany: Robustness Checks

\begin{tabular}{|c|c|c|c|c|}
\hline & $\begin{array}{l}\text { baseline (column (4) } \\
\text { from Table 3) } \\
\text { (1) }\end{array}$ & $\begin{array}{l}\text { relative to West } \\
\text { German migrants, } \\
\text { same local labor } \\
\text { market } \\
\text { (2) }\end{array}$ & $\begin{array}{l}\text { relative to West } \\
\text { German migrants, } \\
\text { same firm } \\
\text { (3) }\end{array}$ & $\begin{array}{l}\text { only cross border } \\
\text { local labor market }\end{array}$ \\
\hline \multicolumn{5}{|l|}{ Panel A: 4 years after childbirth } \\
\hline regularly employed & $0.0792^{\star \star \star}$ & $0.121^{\star \star \star}$ & $0.152^{\star \star \star}$ & $0.104^{\star \star \star}$ \\
\hline (excluding marginal employmnet) & $(0.00821)$ & $(0.00986)$ & $(0.0156)$ & $(0.0149)$ \\
\hline employed & $0.0622^{\star \star \star}$ & $0.110^{\star \star \star}$ & $0.140^{\star \star \star}$ & $0.0679^{\star \star \star}$ \\
\hline (including marginal employment) & $(0.00656)$ & $(0.00811)$ & $(0.0163)$ & $(0.0150)$ \\
\hline \multirow[t]{2}{*}{ full-time employed } & $0.0509^{\star \star \star}$ & $0.0635^{\star \star \star}$ & $0.0801^{\star \star \star}$ & $0.0949^{\star \star \star}$ \\
\hline & $(0.00645)$ & $(0.00730)$ & $(0.0150)$ & $(0.0123)$ \\
\hline \multirow[t]{2}{*}{ downgraded } & $-0.0693^{\star \star \star}$ & $-0.113^{\star \star \star}$ & $-0.140^{\star \star \star}$ & $-0.0996^{\star \star \star}$ \\
\hline & $(0.00865)$ & $(0.00900)$ & $(0.0161)$ & $(0.0146)$ \\
\hline \multicolumn{5}{|l|}{ Panel B: 1 year after childbirth } \\
\hline regularly employed & $0.0366^{\star \star \star}$ & $0.0522^{\star \star \star}$ & $0.0761^{\star \star}$ & $0.0469^{\star \star \star}$ \\
\hline (excluding marginal employment) & $(0.00706)$ & $(0.00795)$ & $(0.0236)$ & $(0.0126)$ \\
\hline \multirow[t]{2}{*}{ full-time employed } & $0.0264^{\star \star \star}$ & $0.0333^{\star \star \star}$ & $0.0468^{\star}$ & $0.0515^{\star \star \star}$ \\
\hline & $(0.00721)$ & $(0.00641)$ & $(0.0210)$ & $(0.00972)$ \\
\hline $\begin{array}{r}\text { Restriction to cross-border local } \\
\text { labor markets }\end{array}$ & no & no & no & yes \\
\hline local labor market ${ }^{\star}$ year of birth FE & yes & yes & yes & yes \\
\hline Firm FE & yes & no & yes & yes \\
\hline Mothers' characteristics at birth & yes & yes & yes & yes \\
\hline Pre-birth employment history & yes & yes & yes & yes \\
\hline N East German & 9.352 & 13.822 & 4.263 & 1.806 \\
\hline N West Germans & 194.269 & 10.164 & 3.745 & 12.463 \\
\hline
\end{tabular}

Notes: The table reports coefficient estimates of the East dummy in regression equation (2), estimated on various samples of first-time mothers who give birth in West Germany. Column (1) reports baseline estimates that compare East Germans who migrated to West Germany prior to giving birth with West German "stayers" and control for local labor market by year of birth fixed effects, firm fixed effects, mothers' control variables at the time of birth and mothers' employment history variables in the three years prior to birth (control set II) as in column (4) of Table 2. In columns (2) and (3), we compare East Germans in West Germany to internal West German migrants who have moved at least the mean distance of the East Germans in the sample (ca. $280 \mathrm{~km}$ ), controlling for local labor market by year of birth fixed effects, mothers' characteristics at the time of birth and employment histories in the three years prior to birth (control set II) in column (2) and additionally firm fixed effects in column (3). In column (4), we compare East and West Germans in the West German parts of the integrated cross-border local labor markets, controlling for the same variables as in column (3). Standard errors clustered on the local labor market level of the place of work when taking maternity leave are reported in parentheses. * statistically significant at the 0.10 level, ${ }^{\star \star}$ at the 0.05 level, ${ }^{\star \star \star}$ at the 0.01 level.

Source: Social Security Records, first-time mothers who signed up for maternity leave in West Germany in $2003-2006$ (columns (1)-(3)), and in the West German parts of cross-border local labor markets in 1997-2006 (column (4)).

\subsection{West German Migrants in East Germany}

Baseline Estimates. We now turn to West Germans who moved to East Germany, and assess whether they continued to behave according to the more traditional culture they experienced as children and teenagers, despite now being fully immersed in the more gender egalitarian East German culture. We report our results in Table 4, which has the same structure as the corresponding Table 2 for East Germans in West Germany. 
Table 4

Differences in Post-Birth Employment Outcomes between East and West German Mothers in East Germany

\begin{tabular}{|c|c|c|c|c|c|}
\hline & $\begin{array}{c}\text { same local labor } \\
\text { market } \\
\text { (1) }\end{array}$ & $\begin{array}{c}\text { same local labor } \\
\text { market, controls } \\
\text { set I } \\
\text { (2) }\end{array}$ & $\begin{array}{l}\text { same local labor } \\
\text { market, controls } \\
\text { set II } \\
\text { (3) }\end{array}$ & $\begin{array}{l}\text { same firm, } \\
\text { controls set II } \\
\text { (4) }\end{array}$ & $\begin{array}{l}\text { same firm, } \\
\text { controls set II, } \\
\text { long-term } \\
\text { migrants } \\
\text { (5) }\end{array}$ \\
\hline \multicolumn{6}{|l|}{ Panel A: 4 years after childbirth } \\
\hline regularly employed & -0.00446 & $0.0146^{\star \star}$ & $0.0172^{\star \star \star}$ & 0.0122 & -0.0123 \\
\hline (excluding marginal employment) & $(0.00802)$ & $(0.00652)$ & $(0.00607)$ & $(0.0116)$ & $(0.0254)$ \\
\hline employed & 0.00615 & $0.0210^{\star \star \star}$ & $0.0232^{\star \star \star}$ & $0.0249^{\star \star}$ & 0.000743 \\
\hline (including marginal employment) & $(0.00910)$ & $(0.00761)$ & $(0.00723)$ & $(0.0123)$ & $(0.0217)$ \\
\hline \multirow[t]{2}{*}{ full-time employed } & $-0.0228^{\star \star \star}$ & -0.00401 & -0.0000473 & 0.00113 & -0.0224 \\
\hline & $(0.00607)$ & $(0.00472)$ & $(0.00469)$ & $(0.0115)$ & $(0.0187)$ \\
\hline \multirow[t]{2}{*}{ downgraded } & 0.000890 & $-0.0196^{\star \star \star}$ & $-0.0227^{\star \star \star}$ & $-0.0173^{\star}$ & 0.0326 \\
\hline & $(0.00758)$ & $(0.00615)$ & $(0.00541)$ & $(0.0104)$ & $(0.0254)$ \\
\hline \multicolumn{6}{|l|}{ Panel B: 1 year after childbirth } \\
\hline regularly employed & 0.000922 & $0.0167^{\star \star}$ & $0.0185^{\star \star}$ & $0.0332^{\star \star}$ & 0.0412 \\
\hline (excluding marginal employment) & $(0.00771)$ & $(0.00727)$ & $(0.00730)$ & $(0.0142)$ & $(0.0256)$ \\
\hline \multirow[t]{2}{*}{ full-time employed } & $-0.0171^{\star \star}$ & -0.000545 & 0.00254 & 0.00809 & 0.0145 \\
\hline & $(0.00742)$ & $(0.00713)$ & $(0.00723)$ & $(0.0136)$ & $(0.0298)$ \\
\hline R-squared & 0.011 & 0.084 & 0.114 & 0.379 & 0.385 \\
\hline Local labor market ${ }^{\star}$ year of birth FE & yes & yes & yes & yes & yes \\
\hline Firm FE & no & no & no & yes & yes \\
\hline Mothers' characteristics at birth & no & yes & yes & yes & yes \\
\hline Pre-birth employment history & no & no & yes & yes & yes \\
\hline N East German natives & 66.195 & 63.894 & 63.894 & 38.859 & 17.450 \\
\hline N West German migrants & 4.211 & 4.135 & 4.135 & 2.332 & 593 \\
\hline
\end{tabular}

Notes: The table reports coefficient estimates of the East dummy in regression equation (2), estimated on a sample of firsttime West German mothers who migrated to East Germany prior to giving birth and East German "stayers". In column (1), we control only for local labor market by year of birth fixed effects. In column (2), we add mothers' control variables at the time of birth (control set I (mother's age, education, occupation (3-digit), wage and full-time status at birth)). In column (3), we additionally include mothers' employment history variables in the three years prior to birth as control variables (control set II (three indicator variables each for full-time employment and regular employment in three years prior to childbirth)). In column (4), we add firm (at the time of birth) fixed effects. In column (5), we restrict the sample to West German migrants who have been in East Germany for at least 6 years prior to giving birth and East German stayers with at least six years of labor market experience prior to giving birth. The R-squared refers to our main outcome variable, regular employment (excluding marginal employment) four years after childbirth. Standard errors clustered on the local labor market level of the place of work when taking maternity leave are reported in parentheses. * statistically significant at the 0.10 level, ${ }^{\star \star}$ at the 0.05 level, ${ }^{\star \star \star}$ at the 0.01 level.

Source: Social Security Records, first-time mothers who signed up for maternity leave in 2003-2006 in East Germany.

Compared to the sizable East-West gap within West German firms, the East-West gaps in East German firms are considerably smaller in magnitude (with the exception of regular employment one year after childbirth) and nearly fully disappear once we focus on West German migrants who had lived in East Germany for at least six years before giving birth in column (5). Thus, in contrast to East German migrants in the West German labor market, West German migrants, who were brought up in a more traditional culture but now encounter a more gender egalitarian one as young adults, seem to adapt their behavior accordingly, in particular after prolonged exposure to East German culture.

Robustness Checks. These findings are robust to the same checks that we conducted for East Germans in the West German labor market. East-West gaps are small in magnitude and insignificant 
when we compare West German migrants to internal East German migrants who moved a similar distance within East Germany and gave birth in the same local labor market in the same year (column (2) of Table 5). ${ }^{25}$ East-West gaps are likewise small and statistically insignificant when we compare East and West Germans within the same firm located in the Eastern part of the integrated cross-border local labor markets (column (3) of Table 5). We conduct a final placebo check in column (4) of Table 5, where we contrast labor market outcomes two years after childbirth of West Germans who migrated to East Germany after giving birth (and thus stayed in West Germany for at least two years post childbirth) and future West German internal movers who gave birth in the same firm. Gaps are close to zero and insignificant, suggesting that West Germans who migrate to East Germany are not systematically more career oriented and more strongly attached to the labor market than West Germans who migrate internally. ${ }^{26}$

Overall, our findings in Tables 2 to 4 reveal a pattern of asymmetric adjustment: whereas East German migrants continue to adhere to the childhood culture they grew up in, West German migrants adjust to their current, more egalitarian cultural environment. Thus, for women who grew up in a more gender traditional environment, their present culture clearly trumps their childhood culture in determining post-birth labor supply decisions, highlighting the importance of the horizontal transmission of culture from East German colleagues and neighbors to West German migrants.

This asymmetric adjustment cannot be explained by differences in partner choice between East and West German migrants. Evidence from the GSOEP shows that a West German migrant is about 30 percentage points more likely than an East German migrant to have a partner who grew up in the same cultural environment as herself ( 75 percent vs. 44 percent; Panel D of Appendix Table A1) - which would predict a stronger adherence to childhood culture among West German migrant mothers than among East German migrant mothers, contrary to what we find. At the same time, the difference in spousal income between West German migrants and East German stayers is considerably larger than the difference in spousal income between West German stayers and East German migrants (Panel D of Appendix Table A1). Hence, differences in spousal income likewise cannot account for the asymmetric adjustment.

25 There are only 319 internal East German migrants, making it infeasible to compare West German migrants and East German internal migrants within the same firm.

26 A similar robustness check is not possible for East Germans who migrate to West Germany, due to the very small number of women who migrate internally after they gave birth. 
Table 5

Differences in Post-Birth Employment Outcomes between East and West German Mothers in East Germany: Robustness Checks

\begin{tabular}{|c|c|c|c|c|}
\hline & $\begin{array}{l}\text { baseline (column (4) } \\
\text { from Table 5) } \\
\text { (1) }\end{array}$ & $\begin{array}{l}\text { relative to East } \\
\text { German migrants, } \\
\text { same local labor } \\
\text { market } \\
\text { (2) }\end{array}$ & $\begin{array}{l}\text { only cross border } \\
\text { local labor market } \\
\text { (3) }\end{array}$ & $\begin{array}{l}\text { Placebo: West } \\
\text { Germans moving to } \\
\text { East after birth vs. } \\
\text { West German internal } \\
\text { migrants } \\
\text { (4) }\end{array}$ \\
\hline \multicolumn{5}{|c|}{ Panel A: 4 years after childbirth ( 2 years in column (4)) } \\
\hline regularly employed & 0.0122 & 0.00137 & 0.0229 & 0.0169 \\
\hline (excluding marginal employment) & $(0.0116)$ & $(0.0219)$ & $(0.0236)$ & $(0.0229)$ \\
\hline employed & $0.0249^{\star \star}$ & 0.0303 & 0.0130 & 0.0159 \\
\hline (including marginal employment) & $(0.0123)$ & $(0.0291)$ & $(0.0233)$ & $(0.0253)$ \\
\hline \multirow[t]{2}{*}{ full-time employed } & 0.00113 & -0.0394 & 0.0182 & -0.000547 \\
\hline & $(0.0115)$ & $(0.0316)$ & $(0.0227)$ & $(0.0170)$ \\
\hline \multirow[t]{2}{*}{ downgraded } & $-0.0173^{\star}$ & -0.00752 & -0.0224 & -0.00972 \\
\hline & $(0.0104)$ & $(0.0218)$ & $(0.0234)$ & $(0.0234)$ \\
\hline \multicolumn{5}{|l|}{ Panel B: 1 year after childbirth } \\
\hline regularly employed & $0.0332^{\star}$ & $-0,0124$ & -0.00350 & -0.000446 \\
\hline (excluding marginal employment) & $(0.0142)$ & $(0.0255)$ & $(0.0228)$ & $(0.0148)$ \\
\hline \multirow[t]{2}{*}{ full-time employed } & 0.00809 & $-0.0348^{\star}$ & -0.00572 & -0.00594 \\
\hline & $(0.0136)$ & $(0.0195)$ & $(0.0196)$ & $(0.0120)$ \\
\hline $\begin{array}{r}\text { Restriction to cross-border local } \\
\text { labor markets }\end{array}$ & no & no & yes & no \\
\hline Local labor market ${ }^{\star}$ year of birth FE & yes & yes & yes & yes \\
\hline Firm FE & yes & no & yes & no \\
\hline Mothers' characteristics at birth & yes & yes & yes & yes \\
\hline Pre-birth employment history & yes & yes & yes & yes \\
\hline N East Germans & 38.850 & 319 & 6.644 & \\
\hline N West Germans & 2.332 & 5.210 & 604 & 2.605 \\
\hline
\end{tabular}

Notes: The table reports coefficient estimates of the East dummy in regression equation (2), estimated on various samples of first-time mothers who give birth in East Germany (except column (4)). Column (1) reports baseline estimates that compare West Germans who migrated to East Germany prior to giving birth with East German "stayers" and control for local labor market by year of birth fixed effects, firm fixed effects, mothers' control variables at the time of birth and mothers' employment history variables in the three years prior to birth (control set II) as in column (4) of Table 4. In column (2), we compare West Germans in East Germany to internal East German migrants who have moved at least the mean distance of the West Germans in the sample (ca. $270 \mathrm{~km}$ ), controlling for local labor market by year of birth fixed effects, mothers' characteristics at the time of birth and employment histories in the three years prior to birth (control set II). In column (3), we compare East and West Germans in the East German parts of the integrated cross-border local labor markets, controlling for the same variables as in column (2) as well as firm fixed effects. In column (4), we conduct a placebo test where we compare employment outcomes 1 and 2 years after birth of West Germans who move to East Germany 2 to 10 years after birth and have never worked in East Germany before giving birth $(\mathrm{N}=796)$ and West Germans who migrate internally (at least $300 \mathrm{~km}$ within West Germany 2 to 10 years after birth $(\mathrm{N}=1809))$. We control for local labor market by year of birth fixed effects, mothers' characteristics at birth and mothers' mothers' employment history variables in the three years prior to birth (control set II). Standard errors clustered on the local labor market level of the place of work when taking maternity leave are reported in parentheses. *statistically significant at the 0.10 level, ${ }^{\star \star}$ at the 0.05 level, ${ }^{\star \star \star}$ at the 0.01 level.

Source: Social Security Records, first-time mothers who signed up for maternity leave in East Germany in 2003-2006 (columns (1)-(2)) and in East German parts of the cross-border local labor markets in 1997-2006 (column (3)). In column (4), we restrict the analysis to first-time mothers who sign up for maternity leave in 2000 in West Germany in migrate across the border to East Germany or internally within West Germany 2-10 years after birth. 


\section{Current versus Past Exposure to a More Gender Egalitarian Culture - Evidence from West German Return Migrants}

Do West German migrant mothers adjust to the more gender egalitarian East German culture only if they gave birth and live in East Germany? Or do they continue to behave more similarly to East German mothers even if they were only exposed to the more egalitarian East German culture in the past but gave birth and live once again in the more traditional West German culture? To address these questions, we next compare post-birth labor market outcomes of West German return migrants (thus with exposure to East Germany in the past) to their West German neighbors or colleagues who always remained in West Germany. We estimate the following specification separately for different points in time since childbirth (indexed by the superscript $k$ ), pooled for mothers who gave birth in West Germany between 1997 and 2006: ${ }^{27}$

$$
Y_{i l f t}^{k}=\beta_{1}^{k} R^{2} \operatorname{turn}_{i}+\theta_{l t}^{k}+\delta_{f}^{k}+x_{i t}^{\prime} \gamma^{k}+v_{i l f t}^{k}
$$

where Return $n_{i}$ is an indicator variable that takes the value 1 if a West German woman worked in East Germany for at least 1.5 years and then returned to West Germany. $\theta_{l t}^{k}$ are year of birth-local labor market fixed effects (at the time of birth), $\delta_{f}^{k}$ are fixed effects that refer to the mother's pre-birth employer, and $x_{i l t}$ denote a mother's pre-birth characteristics (control sets I and II). The parameter of interest $\beta_{1}^{k}$ captures the effects of past full immersion in a more gender egalitarian culture.

Results. The findings in Table 6 generally suggest that not only current, but also past exposure to a more gender egalitarian culture induces mothers to work more and downgrade less after childbirth. Gaps between West German return migrants and West German stayers in regular (excluding marginal) or full-time employment are about 3 to 5 percentage points four years after birth (Panel A), and about 2 to 4 percentage points one year after birth (Panel B), regardless of whether or not we condition on mothers' pre-birth characteristics or pre-birth labor market histories (columns (2) and (3)). Conditioning on pre-birth employer fixed effects in column (4) likewise has only a small impact on the point estimates but substantially increases standard errors. Gaps further persist if we compare West German cross-border return migrants who were exposed to a more egalitarian culture in the past with West German return migrants who migrated internally within West Germany and hence had only limited social interactions with East Germans (column (5)). Comparing these employment gaps with those between East German migrants and West German stayers in Tables 2 and 3, it appears that for women who gave birth in a more traditional environment after having grown up in a more gender egalitarian culture as a child (estimates in Tables 2 and 3) increases employment by about twice as much as having experienced a more gender egalitarian culture only as a young adult (estimates in Table 6).

Overall, these findings suggest that the adjustment of West German migrants to the more gender egalitarian East German culture (Tables 4 and 5) is not driven solely by peer pressure from East German colleagues and neighbors to conform to such norms. Such adaptation may in fact be the

27 We have expanded the birth window by 6 years (1997 to 2006 vs. 2003 to 2006) in order to increase the number of return migrant mothers in West German firms $(\mathrm{N}=1,962)$. 
Table 6

Does past exposure to a more gender egalitarian culture matter? - Differences in post-birth employment outcomes between West German return migrants and West German stayers

\begin{tabular}{|c|c|c|c|c|c|}
\hline & $\begin{array}{c}\text { same local labor } \\
\text { market } \\
\text { (1) }\end{array}$ & $\begin{array}{c}\text { same local labor } \\
\text { market, controls } \\
\text { set I } \\
\text { (2) }\end{array}$ & $\begin{array}{c}\text { same local labor } \\
\text { market, controls } \\
\text { set II } \\
\text { (3) }\end{array}$ & $\begin{array}{l}\text { same firm, } \\
\text { controls set II } \\
\text { (4) }\end{array}$ & $\begin{array}{l}\text { relative to return } \\
\text { migrants within } \\
\text { West Germany } \\
\text { (5) }\end{array}$ \\
\hline \multicolumn{6}{|l|}{ Panel A: 4 years after childbirth } \\
\hline regularly employed & $0.0369^{\star \star \star}$ & $0.0426^{\star \star \star}$ & $0.0433^{\star \star \star}$ & $0.0387^{\star \star}$ & $0.0437^{\star \star \star}$ \\
\hline (excluding marginal employment) & $(0.00967)$ & $(0.00926)$ & $(0.00924)$ & $(0.0171)$ & $(0.0147)$ \\
\hline employed & 0.00650 & 0.0125 & 0.0132 & $0.0296^{\star}$ & 0.0116 \\
\hline (including marginal employment) & $(0.0106)$ & $(0.00983)$ & $(0.00976)$ & $(0.0170)$ & $(0.0142)$ \\
\hline \multirow[t]{2}{*}{ full-time employed } & $0.0567^{\star \star \star}$ & $0.0482^{\star \star \star}$ & $0.0481^{\star \star \star}$ & $0.0319^{\star}$ & $0.0485^{\star \star \star}$ \\
\hline & $(0.00905)$ & $(0.00937)$ & $(0.00938)$ & $(0.0163)$ & $(0.0118)$ \\
\hline \multirow[t]{2}{*}{ downgraded } & -0.0150 & $-0.0247^{\star \star}$ & $-0.0257^{\star \star}$ & -0.0264 & $-0.0355^{\star \star}$ \\
\hline & $(0.0112)$ & $(0.0102)$ & $(0.0101)$ & $(0.0167)$ & $(0.0162)$ \\
\hline \multicolumn{6}{|l|}{ Panel B: 1 year after childbirth } \\
\hline regularly employed & $0.0395^{\star \star \star}$ & $0.0309^{\star \star}$ & $0.0303^{\star \star}$ & 0.0245 & $0.0224^{\star}$ \\
\hline (excluding marginal employment) & $(0.0109)$ & $(0.0101)$ & $(0.00994)$ & $(0.0173)$ & $(0.0123)$ \\
\hline \multirow[t]{2}{*}{ full-time employed } & $0.0426^{\star \star \star}$ & $0.0309^{\star \star \star}$ & $0.0303^{\star \star \star}$ & 0.00899 & $0.0236^{\star}$ \\
\hline & $(0.00893)$ & $(0.00862)$ & $(0.00856)$ & $(0.0140)$ & $(0.0124)$ \\
\hline $\begin{array}{r}\text { Local labor market* by year of birth } \\
\text { FE }\end{array}$ & yes & yes & yes & yes & yes \\
\hline Firm FE & no & no & no & yes & no \\
\hline Mothers' characteristics at birth & no & yes & yes & yes & yes \\
\hline Pre-birth employment history & no & no & yes & yes & yes \\
\hline N West German return migrants & 1.962 & 1.948 & 1.948 & 1.368 & \\
\hline N West German "natives" & 834.204 & 825.771 & 825.771 & 598.032 & 5.420 \\
\hline
\end{tabular}

Notes: The table reports coefficient estimates of the Return dummy in regression equation (3) that compare post-birth employment outcomes between first-time West German mothers who give birth in West Germany but had lived in East Germany for at least 1.5 years in the past (return migrants) and West German "stayers". In column (1), we control only for local labor market by year of birth fixed effects. In column (2), we additionally include mothers' characteristics at the time of birth (control set I (mother's age, education, occupation (3-digit), wage and full-time status at birth)). In column (3), we additionally include mothers' employment history variables in the three years prior to birth as control variables (control set II (three indicator variables each for full-time employment and regular employment in three years prior to childbirth)). In column (4), we add firm (at the time of birth) fixed effects. In column (5), we compare cross-border return migrants $(\mathrm{N}=1874)$ to internal return migrants who have worked far away $(>=300 \mathrm{~km}$ ) from their first place of work within West Germany for at least 1.5 years, and work close to their first place of work when taking maternity leave $(<50 \mathrm{~km})(\mathrm{N}=3546)$. Standard errors clustered on the local labor market level of the place of work when taking maternity leave are reported in parentheses. * statistically significant at the 0.10 level, ${ }^{\star \star}$ at the 0.05 level, ${ }^{\star \star \star}$ at the 0.01 level.

Source: Social Security Records, West German first-time mothers who signed up for maternity leave in West Germany in 19972006.

result of learning from colleagues and neighbors (Fogli and Veldkamp 2011) as well as from the older generation (Fernández 2013), ultimately altering the behavior of West German mothers more permanently. Having been brought up in a culture where working mothers with young children were rare, West German mothers may be uncertain about the impacts of their labor supply choices on their own and their child's well-being. Exposure to East Germans-either through directly observing working mothers or through experiencing the East German context more generally-may mean West German women take in valuable information that leads them to lastingly update their beliefs about the effects early maternal employment. East German women, on the other hand, grew up around working mothers - their own or those of their classmates and friends-and likely attended day care from a young age. They may therefore be considerably less uncertain about the conse- 
quences of working when the child is young and thus have little to learn from their West German colleagues and neighbors. This reasoning would explain why they adhere to their more egalitarian childhood culture even when fully immersed in the more traditional West German culture.

Alternatively, immersion in a more gender egalitarian culture as young adults may, in contrast to immersion in a more traditional culture, induce a permanent change in women's work preferences or identity. ${ }^{28}$ According to this second explanation, traditional work preferences are simply more malleable than gender egalitarian ones.

A third explanation for the differential adjustment concerns asymmetric economic incentives to adapt to a new culture. While for East Germans in West Germany adjusting to the more traditional culture in the West would be economically costly, economic incentives for West Germans in East Germany are in line with adjusting to the more gender egalitarian culture in the East. ${ }^{29}$

\section{Horizontal Transmission within West German Firms - Evidence from the Arrival of East German Colleagues}

The previous analysis demonstrates that when women are fully immersed in a more gender egalitarian culture in adulthood, they start to behave accordingly-even when they return to a more traditional culture. Does the horizontal transmission of culture through colleagues and neighbors rely on being a minority in this different culture; that is, when incentives to comply are potentially the largest? Or is moderate exposure to a more gender egalitarian culture sufficient for horizontal transmission? In this section, we estimate the extent of horizontal spillovers through large immigration flows of East Germans into West German firms to shed light on this question.

\subsection{Empirical Specification}

Prior to 1989, West Germans had very little contact with East German culture since migration from East to West had been virtually impossible since the construction of the Berlin Wall in 1961. After the fall of the Wall in November 1989, between 200,000 and 400,000 East Germans migrated to West Germany annually between 1989 and 1991 (Hunt 2006). Thus, West German women were suddenly exposed to new colleagues who had grown up in a much more gender egalitarian culture. In what follows we exploit the differential inflow of East Germans across observationally equivalent West German firms in the same industry and local labor market in the immediate aftermath of the fall of the Iron Curtain in an effort to assess whether migration can induce cultural change. We compare West German mothers who gave birth prior to the fall of the Berlin Wall, between 1986 and 1988, to observationally equivalent mothers who gave birth after the main migration wave, between 1992

\footnotetext{
28 Prummer and Siedlarek (2017) propose a model where current identity is a weighted average of the host society's culture, past own identity, and peers' past identity and can, in contrast to Akerlof and Kranton (2000), evolve dynamically.

29 This is consistent with Chabé-Ferret (2019) who studies the interplay between culture and economic incentives in decisionmaking and documents that decisions with a higher cost of deviation from the economic optimum are less likely to be influenced by cultural norms.
} 
and 1996, across two types of firms: those that received a large inflow of East German colleagues (our "treatment" firms) versus those that experienced hardly any inflow (our "control" firms). We define treatment firms as those where the share of East Germans among the workforce was least 10 percent in any year over the post-period 1992 to 1996 . Control firms, in contrast, are those where the share of East Germans among the workforce remains very low (below 0.5 percent) throughout the post-period, such that there is very little change in exposure to East Germans in the workplace. ${ }^{30}$ We estimate the following OLS continuous difference-in-differences specification separately for different points in time since childbirth (indexed by the superscript $k$ ), restricting the sample to smaller firms with at most 500 full-time equivalents: ${ }^{31}$

$$
Y_{i f s l t}^{k}=\beta_{1}^{k} \text { post }_{t} * \text { Share }_{f}+x_{i t}^{\prime} \gamma_{1}^{k}+x_{f t}^{\prime} \gamma_{2}^{k}+\delta_{f}^{k}+\rho_{s t}^{k}+\theta_{l t}^{k}+v_{i f s l t}^{k}
$$

where the subscript $i$ indexes the mother, and the subscripts $f, I, s$, and $t$ denote the firm, local labor market, industry, and year where and when the mother gave birth. post $t_{t}$ is an indicator variable that is equal to 1 if the mother gave birth after the fall of the Iron Curtain (between 1992 and 1996) and Share $_{f}$ is the employment share of East Germans in the firm averaged over the post-period years. This way, we eliminate year-to-year variation in the employment share of East Germans within firms during the post-period, which may be correlated with the overall performance of the firm. $x_{i t}$ denote mothers' pre-birth characteristics and labor market trajectories prior to childbirth (control set II); $x_{f t}$ the characteristics of the firm the mother was employed at when she gave birth (the firm's size in full-time equivalents, the firm's mean wage [excluding the wages of those mothers who gave birth in year $t$ ], the share of full-time workers, foreign nationals, and female workers, and the firm's educational and age composition) measured at the time of childbirth; $\delta_{f}^{k}$ are fixed effects that refer to the firm where she was employed at when taking maternity leave; $\rho_{s t}^{k}$ denote industry (at time of birth)-by-year of birth fixed effects; and $\theta_{l t}^{k}$ denote local labor market (at time of birth)-by-year of birth fixed effects.

The parameter of interest $\beta_{1}^{k}$ identifies the effects of a partial exposure to a more gender egalitarian culture, through the arrival of East German colleagues, for mothers who were socialized and still reside in the more traditional West German culture. It therefore captures horizontal transmission of East German culture to West German "native" mothers.

This identification strategy rests on the assumption that absent the inflow of East Germans into treated firms, mothers' post-birth career outcomes would have evolved similarly over time in treatment and control firms. It should be noted that regression equation (9) conditions on region-byyear and industry-by-year fixed effects and thereby allows for the possibility that East Germans self-select into growing local labor markets or industries where mothers may return to work earlier than in declining local labor markets or industries, irrespective of the arrival of East Germans. A remaining concern is that even within the same local labor markets and industries, treatment firms may generally perform better than control firms-after all, they hired a fairly large number of East Germans predominantly during the main migration wave of 1989 to 1991 (years which we exclude in our analysis) and grew at a higher rate than control firms over this period-which in turn

305.25 percent of West German women who gave birth over this period work in a treated firm, and 5.66 percent in control firms. The women in treated firms experienced a substantial change in their social network, with an average share of East German colleagues of 16.5 percent and a standard deviation of 6.5 percent.

31 We further keep only those firms where at least one woman gave birth in the pre-period and at least one in the post-period. 
may affect mother's post-birth labor market decisions irrespective of horizontal transmission. Our results are, however, remarkably robust to the inclusion of firm characteristics at birth and at the time when we measure women's labor supply decisions in order to capture firm-specific trends. Using, as an alternative control group, firms that grew at the same rate as treatment firms over the 1988 to 1992 period but did not hire East Germans, as well as placebo regressions on older women and men further corroborate our conclusion that coefficient estimates of $\beta_{1}^{k}$ primarily capture the horizontal transmission of the more gender egalitarian East German culture.

A second concern is that local labor markets or industries heavily affected by the inflow of East Germans might see a decline in wages and employment opportunities, which could in turn affect women's post-birth career choices, irrespective of any horizontal transmission. The inclusion of industry- and local labor market-by-year of birth fixed effects soak up such "general equilibrium" effects, such that our parameter of interest likely reflects the diffusion of East German culture, rather than economic effects of migration.

\subsection{Results}

Baseline Results. The findings in Table 7 broadly suggest that a larger exposure to East German colleagues in the firm induces West German mothers to return to work earlier and downgrade less after their child is born. Four years after birth (Panel A), the point estimates indicate that a 10 percentage point increase in the share of East German colleagues increases the probability that a West German mother is employed (excluding marginal employment) by between 1.1 and 1.6 percentage points, and reduces the probability that she downgrades to a lower paying occupation by between 1.36 and 1.98 percentage points (largely because of an increase in employment), regardless of which specification is used. ${ }^{32}$ In contrast, full-time employment of West German mothers is not affected by the share of East German colleagues, implying that in the longer term (four years after birth) increased exposure to East German colleagues primarily increases part-time employment of West German mothers. In the short term, one year after birth, a larger exposure to East German colleagues prompts West German mothers to work more not only part-time, but, but also full-time by about 2 and 1.1-1.5 percentage points, respectively, in line with the norm that prevailed in the GDR. Point estimates are remarkably stable across specifications and barely change with the inclusion of individual pre-birth characteristics and work history variables prior to childbirth (column (2)); a wide range of characteristics of the firm where the mother was employed when she took leave that refer to the time of birth (column (3)); and the time when we measure outcomes (column (4)).

While non-trivial, these estimates are somewhat smaller in magnitude than those reported in the existing peer effect literature. Olivetti, Patacchini, and Zenou (forthcoming) find that a one standard deviation increase (around 7 percentage points) in the share of former high school peers with working mothers raises the probability that a woman with children works by 7.7 percentage points. According to estimates by Maurin and Moschion (2009) for France, a 10-percentage point rise in the labor force participation rate of mothers in the surrounding neighborhood increases mothers'

32 We divide the employment share of East Germans by 10 (i. e., the share varies between 0 and 0.1 ) so that the reported coefficients refer to an increase in the employment share of East Germans by 10 percentage points. We do not report results on overall employment (including marginal employment) as the latter is recorded in our data from 1999 only. Prior to 1999 however, marginal employment contracts were fairly uncommon. 
labor force participation by around 6 percentage points. ${ }^{33}$ Comparing our estimates to the employment gaps between West German return migrants and West German stayers in Table 6, a partial, but present-day exposure appears to have a somewhat smaller impact than a full but past exposure to the more gender egalitarian East German culture.

Event Study. The event-study plot in Figure 5 provides additional graphical evidence that the sudden exposure to East German colleagues after the fall of the Iron Curtain accelerated West German mothers' return to work. The figure depicts the evolution of the difference in the probability of working one year after childbirth in treatment firms, which experienced an increase in the share of East Germans by 16.5 percentage points on average, and control firms, where the share of East Germans among the workforce remained below 0.5 percent. Differences in the probability of working are normalized to 0 in 1986. The underlying specification of the event-study plot is equivalent to the specification presented in column (1) of Table 7, which controls for local labor market-by-birth year and industry-by-birth year fixed effects and firm fixed effects. While there is no diverging trend between treatment and control firms in maternal labor supply behavior in the pre-reunification period, a growing difference of around 2 to over 5 percentage points emerges after the sudden arrival of East Germans in the post-reunification period. The probability of working one year after childbirth was similar in the pre-period across treatment and control firms (32.4 and 33.5 percent respectively), which suggests that East German women did not generally select into firms that enabled women to return to work earlier.

33 Nicoletti, Salvanes, and Tominey (2018) in contrast, do not find any significant effects for the influence of neighbors in Norway, but find a sizable effect of an increase in family peer labor supply on Norwegian mothers' labor supply on the intensive but not the extensive margin. 
Figure 5

The effect of East German Colleagues on Regular Employment of West German Mothers One Year After Childbirth (Event Study)

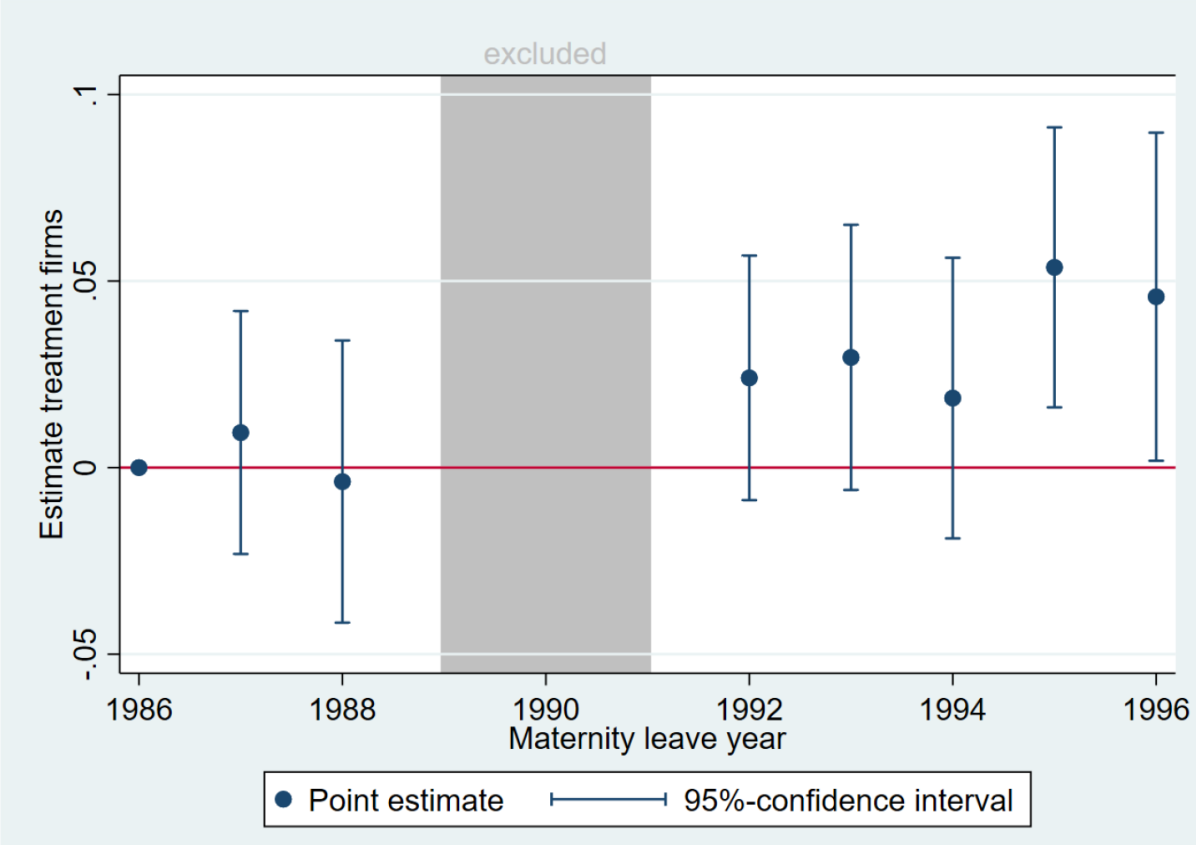

Notes: The figure shows differences in employment probabilities (excluding marginal employment) one year after childbirth between mothers in control and treatment firms over the pre-(1986-1988) and post-period (1992-1996) years. Treatment firms are defined as firms with a share of at least $10 \%$ of East Germans among colleagues in all years of the post period. Control firms are firms with a share of East Germans of at most $0.5 \%$ in any year in the post and the transition period (1989-1991). Regressions control for firm dummies and local labor market by year of birth fixed effects and industry by year of birth fixed effects, as in column (1) in Table 7. Differences between treatment and control firms are normalized to 0 for the last year of the pre-policy period (1986). $95 \%$-confidence intervals are based on standard errors clustered on the labor market level of the place of work when taking maternity leave.

Source: Social Security Records, West German first-time mothers who signed up for maternity leave in West Germany in 19861988 and 1992-1996 in treatment and control firms.

Robustness Checks. Our findings are robust to a battery of checks. For example, including linear firm-specific time trends as additional controls in regression equation (4) barely changes our estimates, as one would expect from the event-study plot (compare columns (1) and (2) in Table 8). Using firms that grew at the same rate as our treatment firms during the main migration years 1988 to 1992 but did not hire East Germans as an alternative control group likewise yields similar estimates (column (3) in Table 8). ${ }^{34}$ Reassuringly, employment outcomes of men and of older women beyond their childbearing years do not appear to be affected by the arrival of East German colleagues (columns (4) and (5) in Table 8). The latter therefore primarily affect post-birth outcomes of West German mothers. Indeed, this is what we would expect if East German colleagues successfully transmit their more gender egalitarian culture to more traditional West German "natives" precisely at this crucial moment when cultural norms are so salient.

Heterogeneous Spillover Effects. Estimates in Panel B of Table 9 further reveal that female colleagues from East Germany, who likely transmit first-hand knowledge regarding returning to work

34 We perform one-to-one matching between treatment and control firms based on relative (full-time equivalent) employment growth between 1988 and 1992. 
Table 7

The Effects of East German Colleagues on Post-Birth Employment Outcomes of West German "Stayers"'

\begin{tabular}{|c|c|c|c|c|}
\hline & $\begin{array}{l}\text { local labor market } \\
\text { and industry by year } \\
\text { of birth FE } \\
\text { (1) }\end{array}$ & $\begin{array}{l}\text { individual controls set } \\
\text { II } \\
\text { (2) }\end{array}$ & $\begin{array}{l}\text { firm controls (at } \\
\text { birth) } \\
\text { (3) }\end{array}$ & $\begin{array}{l}\text { firm controls (at birth } \\
\text { and } 1 \text { or } 4 \text { years after } \\
\text { birth) } \\
\text { (4) }\end{array}$ \\
\hline \multicolumn{5}{|l|}{ Panel A: 4 years after childbirth } \\
\hline regularly employed & $0.0130^{\star \star \star}$ & $0.0123^{\star \star \star}$ & $0.0110^{\star \star}$ & $0.0160^{\star \star \star}$ \\
\hline (excluding marginal employment) & $(0.00438)$ & $(0.00445)$ & $(0.00508)$ & $(0.00575)$ \\
\hline \multirow[t]{2}{*}{ full-time employed } & 0.00149 & 0.00211 & 0.00222 & 0.00750 \\
\hline & $(0.00381)$ & $(0.00361)$ & $(0.00433)$ & $(0.00486)$ \\
\hline \multirow[t]{2}{*}{ downgraded } & $-0.0160^{\star \star \star}$ & $-0.0153^{\star \star \star}$ & $-0.0136^{\star \star \star}$ & $-0.0198^{\star \star \star}$ \\
\hline & $(0.00419)$ & $(0.00422)$ & $(0.00479)$ & $(0.00548)$ \\
\hline \multicolumn{5}{|l|}{ Panel B: 1 year after childbirth } \\
\hline regularly employed & $0.0177^{\star \star \star}$ & $0.0189^{\star \star \star}$ & $0.0211^{\star \star \star}$ & $0.0196^{\star \star \star}$ \\
\hline (excluding marginal employment) & $(0.00497)$ & $(0.00510)$ & $(0.00551)$ & $(0.00542)$ \\
\hline \multirow[t]{2}{*}{ full-time employed } & $0.0117^{\star \star \star}$ & $0.0124^{\star \star}$ & $0.0155^{\star \star \star}$ & $0.0150^{\star \star \star}$ \\
\hline & $(0.00392)$ & $(0.00389)$ & $(0.00413)$ & $(0.00423)$ \\
\hline Local labor market ${ }^{\star}$ year of birth FE & yes & yes & yes & yes \\
\hline Industry ${ }^{\star}$ year of birth FE & yes & yes & yes & yes \\
\hline Mothers' characteristics at birth & no & yes & yes & yes \\
\hline Pre-birth employment history & no & yes & yes & yes \\
\hline Firm characteristics at birth & no & no & yes & yes \\
\hline \multirow{2}{*}{$\begin{array}{r}\text { Firm characteristics } 4 \text { (Panel A) and } \\
1 \text { (Panel B) years after birth } \\
\mathrm{N}\end{array}$} & no & no & no & yes \\
\hline & 74.239 & 73.352 & 71.430 & 65.357 \\
\hline
\end{tabular}

Notes: The table reports the continuous difference-in-differences (DiD) estimate $\left(\beta \_1^{\wedge} k\right)$ from regression equation (4), which measures the effects of a 10 percentage point increase in the share of East Germans among colleagues' post-reunification, estimated on a sample of first-time West German mothers in treatment and control firms who sign up for maternity leave in West Germany in 1986-1988 (pre-period) and 1992-1996 (post-period). Treatment firms are defined as firms with a share of East Germans among colleagues of at least $10 \%$ in all years of the post period. Control firms are firms with an East German share of at most $0.5 \%$ in any of the years in the post period. We restrict the sample to firms with at least 2 and less than 500 employees (full-time equivalents) in each year. The share of East Germans is averaged over the post period. In column (1), we control for firm fixed effects, local labor market (at the time of birth) by year of birth fixed effects, and industry (at the time of birth, 3-digit) by year of birth fixed effects. In column (2), we additionally condition on mothers' characteristics at birth (mother's age, education, occupation (3-digit), wage and full-time status at birth) and mothers' employment history variables in the three years prior to birth as control variables (control set II [three indicator variables each for full-time employment and regular employment in three years prior to childbirth]). In column (3), we add firm characteristics at the time of birth, computed excluding the mother herself (log number of employees (full-time equivalents), log mean wages of full-time employees, the share of foreign nationals, the share full-time employees, the shares of high-skilled and low-skilled employees, the share of women, and shares for age groups 20-29, 30-39, 40-49, 50-59). In column (4), we further add these characteristics of the pre-birth firm 1 (Panel B) or 4 (Panel A) years after birth. Standard errors clustered on the labor market level of the place of work when taking maternity leave are reported in parentheses. * statistically significant at the 0.10 level, ${ }^{\star \star}$ at the 0.05 level, ${ }^{\star \star \star}$ at the 0.01 level.

Source: Social Security Records, West German first-time mothers who signed up for maternity leave in West Germany in 19861988 and 1992-1996 in treatment and control firms.

after birth, have a stronger impact on the post-birth labor market outcomes of West German mothers than do East German male colleagues. In addition, East German colleagues within the same occupation, with whom the mother presumably interacts the most, have a stronger positive impact on a West German mother's probability of working one year after childbirth than do colleagues in other occupations within the firm (Panel C of Table 9). Further, the findings in columns (4) and (5) in Table 9 show that East German colleagues, in particular female colleagues and those in the same occupation, increase the probability that a West German mother continues to work for her pre-birth 
Table 8

The Effects of East German Colleagues on Post-Birth Employment Outcomes of West German "Stayers" (Robustness Checks)

\begin{tabular}{|c|c|c|c|c|c|}
\hline & $\begin{array}{l}\text { baseline (column } \\
\text { (3) for Table 7) } \\
\text { (1) }\end{array}$ & $\begin{array}{c}\text { linear } \\
\text { firm-specific } \\
\text { trends } \\
\text { (2) }\end{array}$ & $\begin{array}{c}\text { alternative } \\
\text { control group } \\
\text { (3) }\end{array}$ & $\begin{array}{l}\text { Placebo check: } \\
\text { Older Women } \\
\text { (age } 45-60 \text { ) } \\
\text { (4) }\end{array}$ & $\begin{array}{l}\text { Placebo check: } \\
\text { Men } \\
\text { (5) }\end{array}$ \\
\hline \multicolumn{6}{|l|}{ Panel A: 4 years after childbirth } \\
\hline regularly employed & $0.0110^{\star \star}$ & $0.0110^{\star \star}$ & $0.0133^{\star \star}$ & $-0,0002$ & 0,0024 \\
\hline (excluding marginal employment) & $(0.00508)$ & $(0.00509)$ & $(0.00658)$ & $(0.00506)$ & $(0.00462)$ \\
\hline full-time employed & $\begin{array}{c}0.00222 \\
(0.00433)\end{array}$ & $\begin{array}{c}0,00215 \\
(0.00434)\end{array}$ & $\begin{array}{c}0.00725 \\
(0.00556)\end{array}$ & $\begin{array}{c}-0,0028 \\
(0.00453)\end{array}$ & $\begin{array}{c}0,0009 \\
(0.00407)\end{array}$ \\
\hline $\begin{array}{r}\text { downgraded (mothers)/wage } \\
\text { growth (placebo) }\end{array}$ & $\begin{array}{l}-0.0136^{\star \star \star} \\
(0.00479)\end{array}$ & $\begin{array}{l}-0.0136^{\star \star \star} \\
(0.00480)\end{array}$ & $\begin{array}{l}-0.0131^{\star} \\
(0.00673)\end{array}$ & $\begin{array}{l}-0.00963 \\
(0.00735)\end{array}$ & $\begin{array}{l}-0.00997 \\
(0.0124)\end{array}$ \\
\hline \multicolumn{6}{|l|}{ Panel B: 1 year after childbirth } \\
\hline $\begin{array}{r}\text { regularly employed } \\
\text { (excluding marginal employment) }\end{array}$ & $\begin{array}{l}0.0211^{\star \star \star} \\
(0.00551)\end{array}$ & $\begin{array}{l}0.0210^{\star \star \star} \\
(0.00553)\end{array}$ & $\begin{array}{l}0.0248^{\star \star \star} \\
(0.00615)\end{array}$ & $\begin{array}{c}0,0008 \\
(0.00451)\end{array}$ & $\begin{array}{l}0,00352 \\
(0.00278)\end{array}$ \\
\hline full-time employed & $\begin{array}{l}0.0155^{\star \star \star} \\
(0.00413)\end{array}$ & $\begin{array}{l}0.0155^{\star \star \star} \\
(0.00415)\end{array}$ & $\begin{array}{l}0.0205^{\star \star \star} \\
(0.00462)\end{array}$ & $\begin{array}{c}0.0034 \\
(0.00345)\end{array}$ & $\begin{array}{c}0.00708^{\star \star \star} \\
(0.00244)\end{array}$ \\
\hline $\mathrm{N}$ & 71.430 & 71.430 & 44.365 & 125.471 & 183.412 \\
\hline
\end{tabular}

Notes: The table reports the continuous difference-in-differences (DiD) estimate $\left(\beta \_1^{\wedge} k\right)$ from regression equation (4), which measures the effects of a 10 percentage point increase in the share of East Germans among colleagues' post-reunification, estimated on a sample of first-time West German mothers in treatment and control firms who sign up for maternity leave in West Germany in 1986-1988 (pre-period) and 1992-1996 (post-period). Treatment firms are defined as firms with a share of East Germans among colleagues of at least $10 \%$ in all years of the post period. Control firms are firms with an East German share of at most $0.5 \%$ in any of the years in the post period. We restrict the sample to firms with at least 2 and less than 500 employees (full-time equivalents) in each year. The share of East Germans is averaged over the post period. Column (1) shows our baseline estimates that control for local labor market by year of birth fixed effects, industry by year of birth fixed effects, mothers' characteristics at birth (control set I) and mothers' employment history in the three years prior to birth (control set II) and firm characteristics at birth, as in column (3) of Table 7. In column (2), we add firm (at the time of birth)-specific linear trends to the continuous DID specification. In column (3), we construct an alternative control group where we match to each treatment firm a control firm that experienced the same employment growth (in full-time equivalents) between 1988 and 1992. In columns (4) and (5), we report placebo estimates for older women (age 45-60) and men aged 18-40 respectively, controlling for the same set of variables as in column (1). As downgrading is rare for these groups, we instead report results for wage growth. Standard errors clustered on the local labor market level of the place of work when taking maternity leave are reported in parentheses. * statistically significant at the 0.1 level, ${ }^{\star \star}$ at the 0.05 level, ${ }^{\star \star \star}$ at the 0.01 level.

Source: Social Security Records. Columns (1) to (3): West German first-time mothers who signed up for maternity leave in West Germany in 1986-1988 and 1992-1996 in treatment and control firms. Columns (4) and (5): all female employees aged 45-60 and all male employees aged 18-40 in treatment and control firms, who were randomly assigned a fake year when they signed up for "maternity leave".

employer, and in her pre-birth occupation within the same firm, four years after birth. This finding suggests that East Germans make the workplace more attractive for West German mothers, as opposed to making it more competitive where mothers feel pressured to return to work early.

How Much Exposure to East German Culture is Needed? Thus far, we have considered a relatively large shock: an increase in the employment share of East Germans by at least 10 percentage points, and 16.5 percent on average. Only 5.25 percent of mothers who gave birth between 1992 and 1996 are employed in such firms. Is such a large shock necessary to induce a change in the behavior of natives? Or might a smaller shock bring about a similar adjustment?

The evidence in Figure 6 suggests that substantial migration shocks larger than 10 percent are needed to generate changes in the behavior of native mothers. In this figure, we relax the definition of the treatment firm and consider all firms where the share of East Germans among the workforce was at least 5 percent (rather than 10 percent, as in our baseline definition) in any year over 
Table 9

The Effects of East German Colleagues on Post-Birth Employment Outcomes of West German "Stayers": Heterogeneous Effects

\begin{tabular}{|c|c|c|c|c|c|}
\hline & $\begin{array}{l}\text { regularly } \\
\text { employed } 1 \text { year } \\
\text { after childbirth } \\
\text { (1) }\end{array}$ & $\begin{array}{l}\text { regularly } \\
\text { employed } 4 \\
\text { years after } \\
\text { childbirth } \\
\text { (2) }\end{array}$ & $\begin{array}{l}\text { downgraded } 4 \\
\text { years after } \\
\text { childbirth } \\
\text { (3) }\end{array}$ & $\begin{array}{l}\text { in same firm } 4 \\
\text { years after } \\
\text { childbirth } \\
\text { (4) }\end{array}$ & $\begin{array}{c}\text { in the same } \\
\text { occupation and } \\
\text { firm } 4 \text { years after } \\
\text { childbirth } \\
\text { (5) }\end{array}$ \\
\hline \multicolumn{6}{|c|}{ Panel A: continuous difference-in-differences estimate } \\
\hline \multirow[t]{2}{*}{ total share } & $0.0211^{\star \star \star}$ & $0.0110^{\star \star}$ & $-0.0136^{\star \star \star}$ & $0.0202^{\star \star \star}$ & $0.0201^{\star \star \star}$ \\
\hline & $(0.00551)$ & $(0.00508)$ & $(0.00479)$ & $(0.00416)$ & $(0.00400)$ \\
\hline \multicolumn{6}{|c|}{ Panel B: East German male vs female colleagues } \\
\hline \multirow[t]{3}{*}{ share female colleagues } & $0.0225^{\star \star \star}$ & $0.0158^{\star \star \star}$ & $-0.0165^{\star \star \star}$ & $0.0241^{\star \star \star}$ & $0.0230^{\star \star \star}$ \\
\hline & $(0.00604)$ & $(0.00536)$ & $(0.00535)$ & $(0.00435)$ & $(0.00429)$ \\
\hline & & & & & $\begin{array}{c}0.00776 \\
(0.00700)\end{array}$ \\
\hline \multicolumn{6}{|c|}{ Panel C: East German colleagues in the same vs different occupation } \\
\hline \multirow[t]{3}{*}{ share in same occupation } & $0.0111^{\star \star}$ & 0.00497 & $-0.00612^{*}$ & $0.0109^{\star \star \star}$ & $0.0103^{\star \star \star}$ \\
\hline & $(0.00353)$ & $(0.00369)$ & $(0.00360)$ & $(0.00262)$ & $(0.00245)$ \\
\hline & & & & & $\begin{array}{c}0.00500 \\
(0.00297)\end{array}$ \\
\hline
\end{tabular}

Notes: The table reports the continuous difference-in-differences (DiD) estimate $\left(\beta \_1^{\wedge} k\right)$ from regression equation (4), which measures the effects of a 10 percentage point increase in the share of East Germans among colleagues' post-reunification, estimated on a sample of first-time West German mothers in treatment and control firms who sign up for maternity leave in West Germany in 1986-1988 (pre-period) and 1992-1996 (post-period). Treatment firms are defined as firms with a share of East Germans among colleagues of at least $10 \%$ in all years of the post period. Control firms are firms with an East German share of at most $0.5 \%$ in any of the years in the post period. We restrict the sample to firms with at least 2 and less than 500 employees (full-time equivalents) in each year. In Panel A, we report baseline estimates that condition on local labor market by year of birth fixed effects, industry by year of birth fixed effects, mothers' characteristics at birth (control set I) and mothers' employment history in the three years prior to birth (control set II) and firm characteristics at birth, as in column (3) of Table 7. In Panels B and C, we control for the same set of variables but split up the share of East German colleagues into the share of female versus male East German colleagues (Panel B) and East German colleagues in the same versus different (3-digit) occupations. Standard errors clustered on the labor market level of the place of work when taking maternity leave are reported in parentheses. ${ }^{\star}$ statistically significant at the 0.10 level, ${ }^{\star \star}$ at the 0.05 level, ${ }^{\star \star \star}$ at the 0.01 level.

Source: Social Security Records, West German mothers who signed up for maternity leave in West Germany in 1986-1988 and 1992-1996 in treatment and control firms.

the post-period 1992 to $1996 .{ }^{35}$ We then estimate a more flexible version of equation (4) with five treatment indicators (corresponding to the 25th, 50th, 75th, and 90th percentile of the share distribution): firms where the East German employment share is less than 7 percent ( $6.4 \%$ on average), between 7 and 9 percent ( $8 \%$ on average), between 9 and 12 percent (10\% on average), between 12 and 17 percent ( $14 \%$ on average), and greater than 17 percent ( $22 \%$ on average). Otherwise, the specification corresponds to that in column (3) of Table 7. The figure is suggestive of a threshold effect at an East German employment share of about 10 percent. A more moderate exposure, of less than 9 percent, to East Germans within a firm has no significant effect on the probability that a West German native mother is employed one year after childbirth. Figure 8 thus suggests that while migration can be a catalyst for cultural change, only exceptionally large migration shocks of at least 10 percentage points bring about behavioral changes in mothers' labor supply.

35 Around 21 percent of mothers who gave birth between 1992 and 1996 are employed in firms that experienced a migration inflow of at least 5 percent. 
Figure 6

The effect of East German Colleagues on Regular Employment of West German Mothers One Year After Childbirth by Treatment Intensity

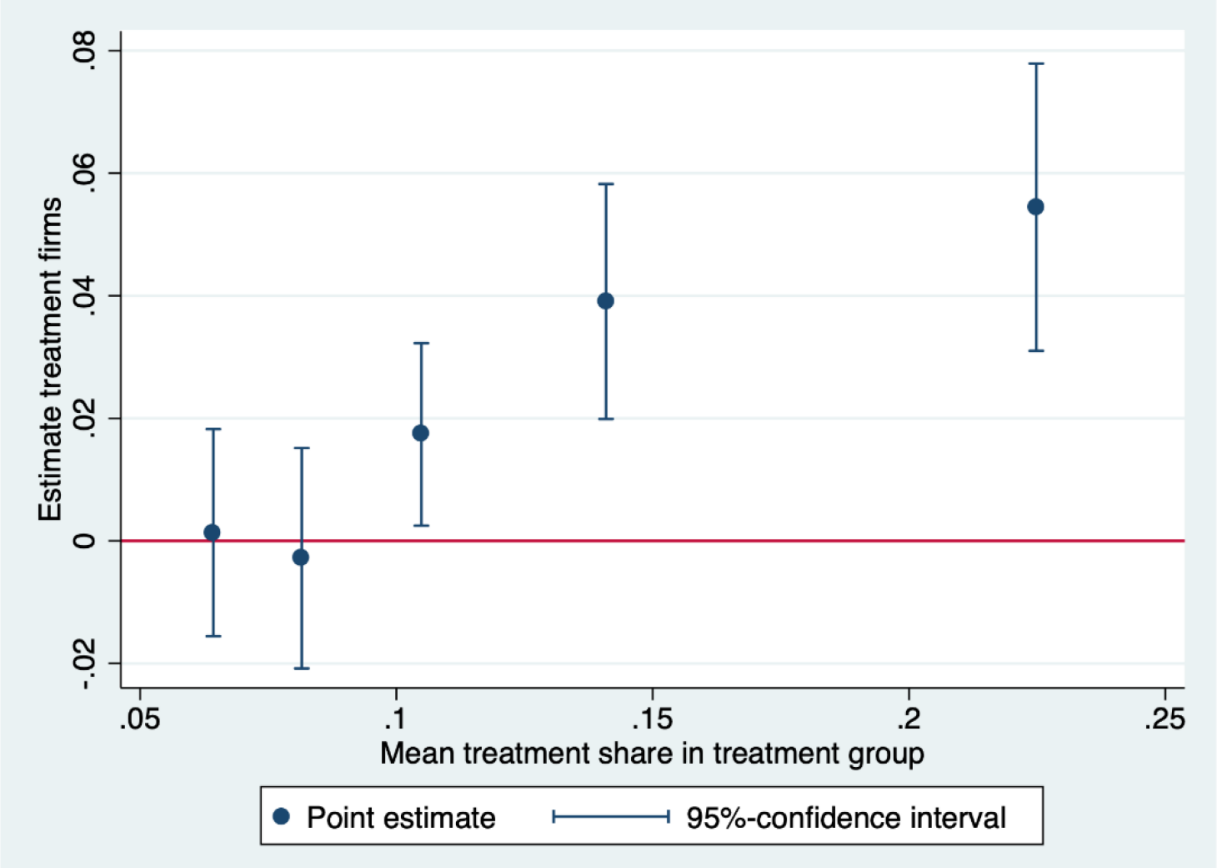

Notes: The figure shows the coefficient estimates from a more flexible version of regression equation (4) that distinguishes between five treatment intensities: a share of East Germans among colleagues of 5-7 \%, 7-9 \%, 9-12 \%, 12-17\% and above $17 \%$, respectively. We relax the definition of treatment firms to firms with a share of East Germans among colleagues of at least $5 \%$ in any of the post-period years. We report the respective mean of the share of East Germans in each of the five treatment intervals on the $x$-axis. We control for local labor market by year of birth fixed effects, industry by year of birth fixed effects, mothers pre-birth characteristics and work history prior to birth (control set II [mother's age, education, occupation (3-digit), wage and full-time status at birth; three indicator variables each for full-time employment and regular employment in three years prior to childbirth], and firm characteristics at the time of birth, computed excluding the mother herself [log number of employees (full-time equivalents), log mean wages of full-time employees, the share of foreign nationals, the share full-time employees, the shares of high-skilled and low-skilled employees, the share of women, and shares for age groups 20-29, 30-39, 40-49, 50-59]). $95 \%$-confidence intervals are based on standard errors clustered on the labor market level of the place of work when taking maternity leave.

Source: Social Security Records, West German first-time mothers who signed up for maternity leave in West Germany in 19861988 and 1992-1996 in newly defined treatment and control firms.

\section{Conclusions}

This paper investigates whether and to what extent mothers' labor supply decisions after childbirth are affected by gender norms and culture. To this end, we use the setting of German reunification, which brought together two distinctly different cultures: the more gender egalitarian culture of East Germany and the more traditional one of West Germany. In particular, we assess which of the two cultures had a more persistent influence on maternal labor supply behavior in the aftermath of reunification, when East and West Germans began to socially interact.

We document four main findings. First, we find sizable remaining differences in the propensity to work between East and West German mothers not only in the aggregate, but also across the former border in economically integrated local labor markets. This result highlights the importance of both 
childhood and current culture in shaping maternal labor supply decisions. Our estimates suggest that West German mothers would be 11.6 percentage points more likely to be employed four years after childbirth if they had grown up in the more gender egalitarian East German culture and had been surrounded by a similar share of East German neighbors and colleagues as were East German mothers at the time of birth.

We then explore whether and to what extent migration from East to West Germany and vice versa led, through increased interactions between East and West Germans, to a convergence of the two cultures. Comparing East and West German mothers who give birth the same firm (located in either West or East Germany) -thereby holding the current cultural environment constant-we document a large asymmetry in the persistence of childhood culture depending on the direction of the move. East German migrants continue to behave according to their more gender egalitarian childhood culture, even when they are a clear minority in a more traditional cultural environment. West German migrants instead experience a cultural shift when fully immersed in a more gender egalitarian culture in adulthood, returning to work earlier after childbirth and thus behaving more similarly to their East German colleagues. Contrasting the employment gap four years after childbirth between East German migrants and West German "natives" of 7.9 percentage points with the East-West employment gap of 11.6 percentage points in the cross-border local labor markets suggests that for women who grew up in a more gender egalitarian environment, childhood culture plays a more important role than current culture in determining maternal labor force participation decisions (68 percent $(0.079 / 0.116)$ vs. 32 percent). Conversely, for women who were brought up in a more traditional environment, current culture clearly trumps childhood culture.

Third, based on the examination of the maternal labor supply of West German return migrants (who were thus exposed to the more gender egalitarian culture in the past), we argue that part of the diffusion of culture is permanent. Specifically, we suggest the latter is the result of either learning about how to combine family and a career or changes in a woman's identity, rather than peer pressure. Our findings also indicate that exposure to a more gender egalitarian culture in adulthood only has about half the effect on early maternal labor supply as having been brought up in this gender egalitarian culture as a child.

Finally, we show that full immersion in a more gender egalitarian culture in adulthood is not needed for West German mothers to deviate from their more traditional childhood culture. Indeed, simple exposure to East German colleagues-in particular East German women-who migrated to West Germany after the fall of the Iron Curtain induces West German women to anticipate their return to work after childbirth, provided that the exposure to East Germans is large enough.

Our paper demonstrates that the East German socialist regime has left an important legacy. Not only has cultural change brought about by socialism had persistent effects on East German women even after the political integration of the East German regime into West Germany, but even more strikingly, the East German gender egalitarian culture has spread to the more traditional West where women have had the opportunity to interact. In the aggregate, however, social interactions between East and West Germans were too limited during the study period to bring about major cultural change among West German mothers. Linearly extrapolating from the observed differences in maternal employment between East and West Germans who gave birth between 1994 and 2007 suggests that convergence would take an additional 132 years, roughly 4-5 generations. 


\section{References}

Adda, Jérôme; Dustmann, Christian; Stevens, Katrien (2017): The Career Costs of Children. Journal of Political Economy 125 (2), pp. 293-337. https://doi.org/10.1086/690952.

Akerlof, George A.; Kranton, Rachel E. (2000): Economics and Identity. The Quarterly Journal of Economics 115 (3), pp. 715-753. https://doi.org/10.1162/003355300554881.

Alesina, Alberto; Fuchs-Schündeln, Nicola (2007): Good-Bye Lenin (or Not?): The Effect of Communism on People's Preferences. American Economic Review 97 (4), pp. 1507-1528. https://doi.org/10.1257/aer.97.4.1507.

Alesina, Alberto; Giuliano; Paola (2015): Culture and Institutions. Journal of Economic Literature 53 (4), pp. 898-944. https://doi.org/10.1257/jel.53.4.898.

Alesina, Alberto; Giuliano, Paola; Nunn, Nathan (2013): On the Origins of Gender Roles: Women and the Plough. The Quarterly Journal of Economics 128 (2), pp. 469-530.

Angelov, Nikolay; Johansson, Per; Lindahl, Erica (2016): Parenthood and the Gender Gap in Pay. Journal of Labor Economics 34 (3), pp. 545-579. https://doi.org/10.1086/684851.

Bauernschuster, Stefan; Rainer, Helmut (2011): Political Regimes and the Family: How Sex-Role Attitudes Continue to Differ in Reunified Germany. Journal of Population Economics, April. https://doi.org/10.1007/s00148-011-0370-z.

Beblo, Miriam; Görges, Luise (2018): On the Nature of Nurture. The Malleability of Gender Differences in Work Preferences. Journal of Economic Behavior \& Organization 151 (July), pp. 19-41. https://doi.org/10.1016/j.jebo.2018.05.002.

Becker, Sascha O.; Mergele, Lukas; Woessmann, Ludger (2020): The Separation and Reunification of Germany: Rethinking a Natural Experiment Interpretation of the Enduring Effects of Communism. SSRN Scholarly Paper ID 3555591. Rochester, NY: Social Science Research Network. https://papers.ssrn.com/abstract=3555591.

Berge, Philipp vom; Burghardt, Anja; Trenkle, Simon (2013): Sample of integrated labour market biographies. Regional-File 1975-2010 (SIAB-R 7510). FDZ-Datenreport Nr. 9 (en).

Bertrand, Marianne: Kamenica, Emir; Pan, Jessica (2015): Gender Identity and Relative Income within Households. The Quarterly Journal of Economics 130 (2), pp. 571-614. https://doi.org/10.1093/qje/qjv001.

Bisin, Alberto; Verdier, Thierry (2011): Chapter 9 - The Economics of Cultural Transmission and Socialization. In: Handbook of Social Economics, edited by Jess Benhabib, Alberto Bisin, and Matthew O. Jackson, 1, pp. 339-416. North-Holland. https://doi.org/10.1016/B978-0-444-53187-2.00009-7.

Blau, Francine (2015): Immigrants and Gender Roles: Assimilation vs. Culture. IZA Journal of Migration and Development 4 (1), pp. 1-21.

Blau, Francine D.; Kahn, Lawrence M.; Yung-Hsu Liu, Albert; Papps, Kerry L. (2013): The Transmission of Women's Fertility, Human Capital, and Work Orientation across Immigrant Generations. Journal of Population Economics 26 (2), pp. 405-435. https://doi.org/10.1007/s00148-012-0424-x.

Blau, Francine D.; Kahn, Lawrence M. (2007): Changes in the Labor Supply Behavior of Married Women: 1980-2000. Journal of Labor Economics 25 (3), pp. 393-438. https://doi.org/10.1086/513416. 
Bundesinstitut für Berufsbildung (2018): Datenreport zum Berufsausbildungsbericht 2018. Informationen und Analysen zur Entwicklung der beruflichen Bildung. Bonn. https://www.bibb.de/datenreport/de/datenreport_2018.php.

Bursztyn, Leonardo; González, Alessandra L.; Yanagizawa-Drott, David (2018): Misperceived Social Norms: Female Labor Force Participation in Saudi Arabia. 2018042. Working Papers. Human Capital and Economic Opportunity Working Group. https://ideas.repec.org/p/hka/wpaper/2018-042.html.

Busch, Oliver; Weigert, Benjamin (2010): Where Have All the Graduates Gone? Internal Cross-State Migration of Graduates in Germany 1984-2004. The Annals of Regional Science 44 (3), pp. 559-572.

Campa, Pamela; Serafinelli, Michel (2018): Politico-Economic Regimes and Attitudes: Female Workers under State Socialism. The Review of Economics and Statistics 101 (2), pp. 233248. https://doi.org/10.1162/rest_a_00772.

Cardoso, Ana Rute; Morin, Louis-Philippe (2018): Can Economic Pressure Overcome Social Norms? The Case of Female Labor Force Participation. Working Paper 11822. IZA Discussion Papers. https://www.econstor.eu/handle/10419/185282.

Chabé-Ferret, Bastien (2019): Adherence to Cultural Norms and Economic Incentives: Evidence from Fertility Timing Decisions. Journal of Economic Behavior \& Organization 162 (June), pp. 24-48. https://doi.org/10.1016/j.jebo.2019.04.003.

Charles, Kerwin Kofi; Guryan, Jonathan; Pan, Jessica (2018): The Effects of Sexism on American Women: The Role of Norms vs. Discrimination. Working Paper 24904. National Bureau of Economic Research. https://doi.org/10.3386/w24904.

Cornelissen, Thomas; Dustmann, Christian; Raute, Anna; Schönberg, Uta (2018): Who Benefits from Universal Child Care? Estimating Marginal Returns to Early Child Care Attendance. Journal of Political Economy 126 (6), pp. 2356-2409. https://doi.org/10.1086/699979.

Eugster, Beatrix; Lalive, Rafael; Steinhauer, Andreas; Zweimüller, Josef (2011): The Demand for Social Insurance: Does Culture Matter? The Economic Journal 121 (556), pp. 413-448. https://doi.org/10.1111/j.1468-0297.2011.02479.x.

Eugster, Beatrix; Lalive, Rafael; Steinhauer, Andreas; Zweimüller, Josef (2017): Culture, Work Attitudes, and Job Search: Evidence from the Swiss Language Border. Journal of the European Economic Association 15 (5), pp. 1056-1100. https://doi.org/10.1093/jeea/jvw024.

Farré, Lídia; Vella, FRancis (2013): The Intergenerational Transmission of Gender Role Attitudes and Its Implications for Female Labour Force Participation. Economica 80 (318), pp. 219-247. https://doi.org/10.1111/ecca.12008.

Fernández, Raquel (2007): Women, Work, and Culture. Journal of the European Economic Association 5 (2-3), pp. 305-332.

Fernández, Raquel (2011): Chapter 11 - Does Culture Matter? In: Handbook of Social Economics, edited by Jess Benhabib, Alberto Bisin, and Matthew O. Jackson, 1, pp. 481-510. North-Holland. https://doi.org/10.1016/B978-0-444-53187-2.00011-5.

Fernández, Raquel (2013): Cultural Change as Learning: The Evolution of Female Labor Force Participation over a Century. American Economic Review 103 (1), pp. 472-500. https://doi.org/10.1257/aer.103.1.472. 
Fernández, Raquel; Fogli, Alessandra (2009a): Culture: An Empirical Investigation of Beliefs, Work, and Fertility. American Economic Journal: Macroeconomics 1 (1), pp. 146-77. https://doi.org/10.1257/mac.1.1.146.

Fernández, Raquel; Fogli, Alessandra (2009b): Culture: An Empirical Investigation of Beliefs, Work, and Fertility. American Economic Journal: Macroeconomics 1 (1), pp. 146-177. https://doi.org/10.1257/mac.1.1.146.

Fernández, Raquel; Fogli, Alessandra; Claudia Olivetti (2004): Mothers and Sons: Preference Formation and Female Labor Force Dynamics. The Quarterly Journal of Economics 119 (4), pp. 1249-1299. https://doi.org/10.1162/0033553042476224.

Fernández, Raquel; Parsa, Sahar; Viarengo, Martina (2019): Coming out in America: AIDS, Politics, and Cultural Change. Working Paper 25697. National Bureau of Economic Research. https://doi.org/10.3386/w25697.

Fogli, Alessandra; Veldkamp, Laura (2011): Nature or Nurture? Learning and the Geography of Female Labor Force Participation. Econometrica 79 (4), pp. 1103-1138. https://doi.org/10.3982/ECTA7767.

Fortin, Nicole M. (2005): Gender Role Attitudes and the Labour-Market Outcomes of Women across OECD Countries. Oxford Review of Economic Policy 21 (3), pp. 416438. https://doi.org/10.1093/oxrep/gri024.

Fortin, Nicole M. (2015): Gender Role Attitudes and Women's Labor Market Participation: Opting-Out, AIDS, and the Persistent Appeal of Housewifery. Annals of Economics and Statistics, no. 117/118, pp. 379-401. https://doi.org/10.15609/annaeconstat2009.117118.379.

Fuchs-Schündeln, Nicola; Schündeln, Matthias (2009): Who Stays, Who Goes, Who Returns? Economics of Transition 17 (4), pp. 703-738. https://doi.org/10.1111/j.14680351.2009.00373.x.

Gay, Victor (2019): The Legacy of the Missing Men: The Long-Run Impact of World War I on Female Labor Force Participation. SSRN Scholarly Paper ID 3069582. Rochester, NY: Social Science Research Network. https://papers.ssrn.com/abstract=3069582.

Giuliano, Paola (2007): Living Arrangements in Western Europe: Does Cultural Origin Matter? Journal of the European Economic Association 5 (5), pp. 927-952. https://doi.org/10.1162/JEEA.2007.5.5.927.

Giuliano, Paola (2016): Female Labour Force Participation: Persistence and Evolution. In: The New Palgrave Dictionary of Economics, 1-8. London: Palgrave Macmillan UK. https://doi.org/10.1057/978-1-349-95121-5_2888-1.

Giuliano, Paola (2018): Gender. The Oxford Handbook of Women and the Economy, July. https://doi.org/10.1093/oxfordhb/9780190628963.013.29.

Giuliano, Paola; Nunn, Nathan (2017): Understanding Cultural Persistence and Change. Working Paper 23617. National Bureau of Economic Research. https://doi.org/10.3386/w23617.

Grunow, Daniela; Müller, Dana (2012): Kulturelle und strukturelle Faktoren bei der Rückkehr in den Beruf: Ostdeutsche, westdeutsche und ost-west-mobile Mütter im Vergleich (Transition Back to Work: Comparing Mothers in Eastern Germany, Western Germany, and East-West Mobile Mothers). IAB-Discussion Paper Nr. 2. https://ideas.repec.org/p/iab/iabdpa/201202.html. 
Guiso, Luigi; Sapienza, Paola; Zingales, Luigi (2006): Does Culture Affect Economic Outcomes? Journal of Economic Perspectives 20 (2), pp. 23-48. https://doi.org/10.1257/jep.20.2.23.

Gustafsson, Siv; Jacobsson, Roger (1985): Trends in Female Labor Force Participation in Sweden. Journal of Labor Economics 3 (1), pp. 256-274.

Heise, Sebastian; Porzio, Tommaso (2019): Workers' Home Bias and Spatial Wage Gaps: Lessons from the Enduring Divide between East and West Germany. Unpublished.

Hotz, V. Joseph; Johansson, Per; Karimi, Arizo (2017): Parenthood, Family Friendly Workplaces, and the Gender Gaps in Early Work Careers. Working Paper 24173. National Bureau of Economic Research. https://doi.org/10.3386/w24173.

Hunt, Jennifer (2006): Staunching Emigration from East Germany: Age and the Determinants of Migration. Journal of the European Economic Association 4 (5), pp. 1014-1037. https://doi.org/10.1162/JEEA.2006.4.5.1014.

Jarotschkin, Alexandra; Zhuravskaya, Ekatarina (2019): Diffusion of Gender Norms: Evidence from Stalin's Ethnic Deportations. SSRN Scholarly Paper ID 3417682. Rochester, NY: Social Science Research Network. https://papers.ssrn.com/abstract=3417682.

Kaminsky, Anna (2016): Frauen in der DDR. Berlin: Ch. Links Verlag.

Kleven, Henrik; Landais, Camille; Posch, Johanna; Steinhauer, Andreas; Zweimüller, Josef (2019): Child Penalties across Countries: Evidence and Explanations. AEA Papers and Proceedings 109 (May), pp. 122-126. https://doi.org/10.1257/pandp.20191078.

Kleven, Henrik; Landais, Camille; Søgaard, Jakob Egholt (2019): Children and Gender Inequality: Evidence from Denmark. American Economic Journal: Applied Economics 11 (4), pp. 181-209. https://doi.org/10.1257/app.20180010.

Kleven, Henrik; Landais, Camille; Søgaard, Jakob Egholt (n.d.): Children and Gender Inequality: Evidence from Denmark. American Economic Journal: Applied Economics. Accessed June 13, 2019. https://doi.org/10.1257/app.20180010.

Kosfeld, Reinhold; Werner, Alexander (2012): Deutsche Arbeitsmarktregionen - Neuabgrenzung nach den Kreisgebietsreformen 2007-2011. Raumforschung und Raumordnung 70 (1), pp. 49-64. https://doi.org/10.1007/s13147-011-0137-8.

Kuziemko, Ilyana; Pan, Jessica; Shen, Jenny; Washington, Ebonya (2018): The Mommy Effect: Do Women Anticipate the Employment Effects of Motherhood? Working Paper 24740. National Bureau of Economic Research. https://doi.org/10.3386/w24740.

Lippmann, Quentin; Georgieff, Alexandre; Senik, Claudia (2019): Undoing Gender with Institutions: Lessons from the German Division and Reunification. SSRN Scholarly Paper ID 3390199. Rochester, NY: Social Science Research Network. https://papers.ssrn.com/abstract=3390199.

Maurin, Eric; Moschion, Julie (2009): The Social Multiplier and Labor Market Participation of Mothers. American Economic Journal: Applied Economics 1 (1), pp. 251-272. https://doi.org/10.1257/app.1.1.251.

Müller, Dana; Strauch, Katharina (2017): Identifying Mothers in Administrative Data. FDZMethodenreport 13 (en). https://ideas.repec.org/p/iab/iabfme/201713_en.html.

Nicoletti, Cheti; Salvanes, Kjell G.; Tominey, Emma (2018): The Family Peer Effect on Mothers' Labor Supply. American Economic Journal: Applied Economics 10 (3); pp. 206-234. https://doi.org/10.1257/app.20160195. 
Olivetti, Claudia; Patacchini, Eleonora; Zenou, Yves (n.d.): Mothers, Peers, and GenderRole Identity. Journal of the European Economic Association. Accessed June 13, 2019. https://doi.org/10.1093/jeea/jvy050.

Prummer, Anja; Siedlarek, Jan-Peter (2017): Community Leaders and the Preservation of Cultural Traits. Journal of Economic Theory 168 (March), pp. 143-176. https://doi.org/10.1016/j.jet.2016.12.007.

Raute, Anna (2019): Can Financial Incentives Reduce the Baby Gap? Evidence from a Reform in Maternity Leave Benefits. Journal of Public Economics 169 (January), pp. 203-222. https://doi.org/10.1016/j.jpubeco.2018.07.010.

Rosenfeld, Rachel A.; Trappe, Heike; Gornick, Janet C. (2004): Gender and Work in Germany: Before and After Reunification. Annual Review of Sociology 30 (1), pp. 103-124. https://doi.org/10.1146/annurev.soc.30.012703.110531.

Schmitz, Sophia; Weinhardt, Felix (2019): Immigration and the Evolution of Local Cultural Norms. SSRN Scholarly Paper ID 3435384. Rochester, NY: Social Science Research Network. https://papers.ssrn.com/abstract=3435384.

Schönberg, Uta (2009): Does the IAB Employment Sample Reliably Identify Maternity Leave Taking?: A Data Report. Zeitschrift für ArbeitsmarktForschung - Journal for Labour Market Research 42 (1), pp. 49-70.

Schönberg, Uta; Ludsteck, Johannes (2014): Expansions in Maternity Leave Coverage and Mothers' Labor Market Outcomes after Childbirth. Journal of Labor Economics 32 (3), pp. 469-505. https://doi.org/10.1086/675078.

Statistische Ämter des Bundes und der Länder (2008): Kindertagesbetreuung Regional 2007: Ein Vergleich aller 439 Kreise in Deutschland. Wiesbaden: Statistisches Bundesamt.

Steinhauer, Andreas (2018): Working Moms, Childlessness, and Female Identity. SSRN Scholarly Paper ID 3178100. Rochester, NY: Social Science Research Network. https://papers.ssrn.com/abstract=3178100.

Thornton, Arland; Alwin, Duane F.; Camburn, Donald (1983): Causes and Consequences of Sex-Role Attitudes and Attitude Change. American Sociological Review 48 (2), pp. 211-227. https://doi.org/10.2307/2095106.

Trappe, Heike (1996): Work and Family in Women's Lives in the German Democratic Republic. Work and Occupations 23 (4), pp. 354-377. https://doi.org/10.1177/0730888496023004003.

Trappe, Heike; Rosenfeld, Rachel A. (2000): How Do Children Matter? A Comparison of Gender Earnings Inequality for Young Adults in the Former East Germany and the Former West Germany. Journal of Marriage and Family 62 (2), pp. 489-507.

Weisser, Reinhard A. (2019): How Personality Shapes Study Location Choices. Research in Higher Education, March. https://doi.org/10.1007/s11162-019-09550-2. 


\section{Appendix: Imputation of East and West Germans}

We develop an imputation technique for classifying a person as East or West German. We proceed in three steps. In the first step, we use the first place of work to indicate whether a person is East or West German. If the first spell of a person is an unemployment spell, we use the regional information of the job center (Agenturbezirke) in which the person is registered as the basis for the imputation. From these regional variables, we compute a binary variable classifying a person as East or West German.

When East German firms entered the pool of social security records after the fall of the Iron Curtain, we initially observe an unusually large share of missing places of work as East German firms were not yet fully integrated into the reporting system. Therefore, in a second step, we classify as East German all women who we observe as working for the first time during the transition period (19891991) and whose place of work is reported as missing.

From 1992 onwards, data for East Germany can be collected reliably (vom Berge, Burghardt, and Trenkle 2013). By that time, many East Germans had migrated to West Germany for work (Hunt 2006), such that their first place of work may be recorded as in West Germany. In order not to accidentally misclassify these early migrants as West German, we consider in a third step a worker as East German when she enters the social security data for the first time between 1989 and 1991 and is above a certain age, even if her first place of work is in West Germany. The age thresholds that we apply vary by education at labor market entry: 29 for individuals with a university-level education (Universität or Fachhochschule), 26 for those with an upper-track high school degree (Abitur) and vocational degree, 23 for all other individuals. Prior to 1989, before East Germans had the opportunity to migrate to West Germany, only very few West Germans entered the social security records at older ages, such that the probability of erroneously misclassifying a West German as an East German should be small. It should be noted that the third imputation step has a minimal impact on our estimates in Sections 4 and 5 where we focus on mothers who gave birth between 2003 and 2006, as the majority of these mothers entered the social security records in 1992 or later. 
Figure A.1

Cross-Border Local Labor Markets

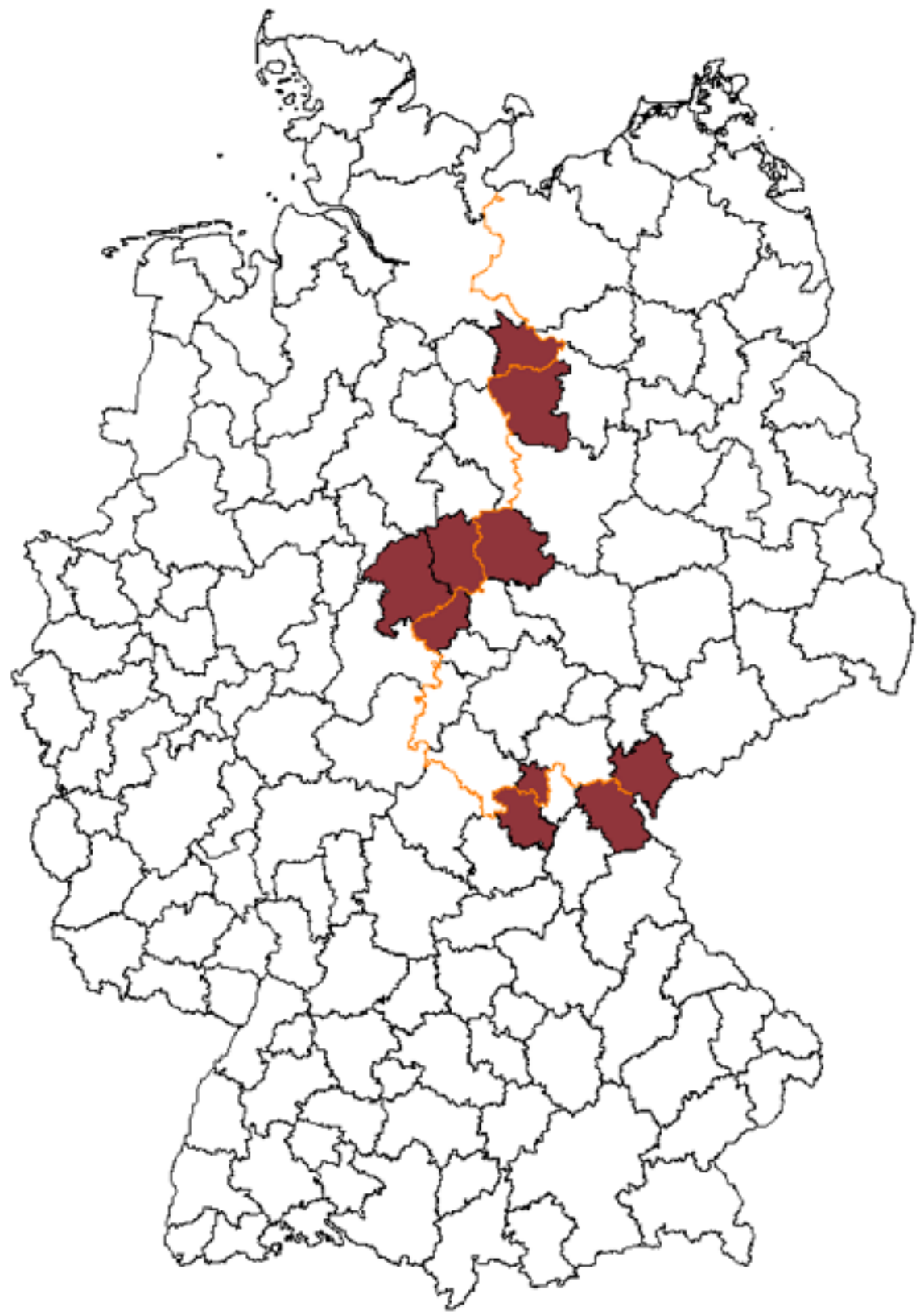

Notes: The map depicts the 141 local labor markets defined by 2009 commuter flows. The orange line depicts the former inner-German border, and the labor market areas highlighted in dark are the 5-integrated cross-border local labor markets: Göttingen, Goslar, Lüchow-Dannenberg, Coburg, and Hof.

Source: Definition of local labor markets follows Kosfeld and Werner (2012). Shapefile obtained from the Federal Government for Cartography and Geodesy (Bundesamt für Kartographie and Geodäsie). 
Table A.1

East and West German Migrants and Stayers: Descriptive Statistics

\begin{tabular}{|c|c|c|c|c|}
\hline & West in West & West in East & East in East & East in West \\
\hline \multicolumn{5}{|c|}{ Panel A: Mothers' Characteristics at Childbirth (Social Security Records) } \\
\hline age at birth & 28.617 & 28.063 & 28.604 & 29.994 \\
\hline low education & 0.157 & 0.082 & 0.108 & 0.084 \\
\hline medium education & 0.730 & 0.794 & 0.802 & 0.811 \\
\hline high education & 0.113 & 0.124 & 0.090 & 0.105 \\
\hline pre-birth real daily earnings & 68.151 & 51.315 & 48.599 & 69.685 \\
\hline full-time employed & 0.802 & 0.793 & 0.753 & 0.812 \\
\hline \multicolumn{5}{|c|}{ Panel B: Mothers' Employment Outcomes 4 Years After Childbirth (Social Security Records) } \\
\hline $\begin{array}{r}\text { employed (including marginal } \\
\text { employment) }\end{array}$ & 0.535 & 0.635 & 0.640 & 0.616 \\
\hline regularly employed & 0.401 & 0.568 & 0.562 & 0.509 \\
\hline employed full-time & 0.199 & 0.361 & 0.336 & 0.261 \\
\hline downgraded & 0.655 & 0.515 & 0.516 & 0.559 \\
\hline \multicolumn{5}{|c|}{ Panel C: Share East Germans in neighborhood and firm (Social Security Records) } \\
\hline share East German neighbors & 0,050 & 0,938 & 0,950 & 0,056 \\
\hline Share East German colleagues & 0,047 & 0,858 & 0,925 & 0,105 \\
\hline $\mathrm{N}$ & 327.780 & 4.597 & 69.495 & 15.337 \\
\hline
\end{tabular}

Panel D: Characteristics of spouses (German Socio-Economic Panel)

\begin{tabular}{r|c|c|c|c} 
has partner & 0,916 & 0,881 & 0,870 & 0,890 \\
partner is of same origin (East or West) & 0,98 & 0,75 & 0,98 & 1933,40 \\
spousal gross labor income & 3065,65 & 4515,20 & 1323,24 & 1887,09 \\
spousal net labor income & 2026,79 & 2773,76 & 118 & 648 \\
$\mathrm{~N}$ & & 118 &
\end{tabular}

Source: Panels A to C: Social Security Records, first-time mothers who signed up for maternity leave in 2003-2006. Panel D: German Socio Economic Panel (GSOEP), women whose first child is age 0-5 in 1990-2010. 


\section{Imprint}

IAB-Discussion Paper 30|2020

Publication date

2. October 2020

Editorial address

Institute for Employment Research

of the Federal Employment Agency

Regensburger Straße 104

90478 Nuremberg

All rights reserved

Reproduction and distribution in any form - also in parts - requires the permission of the IAB

Download

http://doku.iab.de/discussionpapers/2020/dp3020.pdf

All publications in the series "IAB-Discussion Paper" can be downloaded from

https://www.iab.de/en/publikationen/discussionpaper.aspx

Website

http://www.iab.de

ISSN

2195-2663

For further inquiries contact the author(s)

Barbara Boelmann

Department of Economics, University College London, CReAM and University of Cologne, 30 Gordon Street, London WC1H OAX, United Kingdom

E-mail barbara.boelmann.14@ucl.ac.uk

Anna Raute

School of Economics and Finance, Queen Mary University of London, CReAM and CEPR, Mile End Road, London E1 4NS, United Kingdom

E-mail a.raute@qmul.ac.uk

Uta Schönberg

Department of Economics, University College London, CReAM and IAB, 30 Gordon Street, London WC1H OAX, United Kingdom

E-mail u.schoenberg@ucl.ac.uk 